\title{
Effect of Different Synthesis Approaches on Structural and Thermal Properties of Lanthanide(III) Metal-Organic Frameworks Based on the 1H-Pyrazole-3,5-Dicarboxylate Linker
}

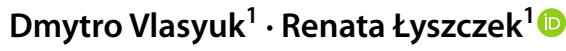

Received: 19 January 2021 / Accepted: 3 May 2021 / Published online: 17 May 2021

(c) The Author(s) 2021

\begin{abstract}
The impact of different synthetic procedures such as: hydrothermal, mechanochemical and precipitation on the structure and thermal properties of coordination polymers of $1 \mathrm{H}$-pyrazole-3,5-dicarboxylic acid $\left(\mathrm{H}_{3}\right.$ pdca $)$ with selected lanthanide ions was determined. The prepared complexes of the general formula: $\mathrm{Ln}_{2}(\mathrm{Hpdca})_{3} \cdot \mathrm{nH}_{2} \mathrm{O}$, where $\mathrm{Ln}=\mathrm{Eu}(\mathrm{III}), \mathrm{Nd}(\mathrm{III}), \mathrm{Tb}(\mathrm{III})$ and $\operatorname{Er}(\mathrm{III}) ; \mathrm{n}=6$ or 7 were fully investigated by: elemental analysis, Energy-Dispersive X-Ray (ED-XRF) and infrared (ATR-FTIR) spectroscopy, powder as well as single-crystal X-ray diffraction methods and thermal analysis (TG-DSC and TG-FTIR) in various atmospheres. It was proved that all used strategies offer high yields of reactions along with crystallinity of the obtained products. The X-ray diffraction methods allowed to conclude that the complexes with the same metal ions exhibit the same crystal structure despite different synthesis routes. On the other hand, the coordination polymers of $\mathrm{Eu}(\mathrm{III})$, $\mathrm{Tb}(\mathrm{III})$ and $\mathrm{Er}$ (III) prepared under different conditions are isomorphous. Only neodymium(III) compounds have a different crystal structure. Thermal stability of the produced complexes was correlated with the synthesis conditions, in particular with the way of energy supply. It was found that the highest thermal stability was exhibited by the complexes prepared under the hydrothermal conditions. Additionally, based on the volatile products of metal complexes decomposition, the mechanism of their pyrolysis was proposed in relation to their structures.
\end{abstract}

Keywords Lanthanides · Coordination polymers $\cdot$ Hydrothermal method $\cdot$ Mechanochemistry $\cdot$ Precipitation procedure $\cdot$ TG-FTIR · TG-DSC · Pyrolysis

\section{Introduction}

Recently, coordination polymers (CPs) have been regarded as a new group of multifunctional materials due to their intriguing physicochemical properties resulting from the combination of inorganic and organic building blocks. Selfassembly of metal ions or metal clusters with the bridging organic ligands resulted in the formation of "infinite" metal-ligand polymeric structures of different dimensionalities [1-5].

Porous coordination polymers called also metal-organic frameworks (MOFs) are crystalline materials which display

Renata Łyszczek

renata.lyszczek@poczta.umcs.lublin.pl

1 Faculty of Chemistry, Department of General and Coordination Chemistry and Crystallography, Institute of Chemical Sciences, Maria Curie-Skłodowska University in Lublin, M. C. Skłodowskiej Sq. 2, 20-031 Lublin, Poland permanent porosity with the enormous internal surface area and large structural diversity. These features contribute to a wide spectrum of applications including gas capture and storage, molecules separation, ion-exchange, drug delivery, chemical sensing and catalysis. Metal-organic frameworks have attracted tremendous interest in most prolific areas of materials chemistry research. The remarkable progress of MOFs could be explained by their efficient tailorable chemistry as well as ability of fine tuning the structure using different metal cations and organic ligands [6-18]. Coordination polymers based on the lanthanide ions offer not only extremely intriguing topological architectures arising from high and variable coordination number but also a wide range of potential applications derived from their extraordinary magnetic and luminescence properties. These characteristics make them very attractive materials in many advanced technologies such as photonics and optoelectronics, chemical sensing, catalysis and energy storage [19-33]. An important factor in the strategy of coordination polymer construction 
is the selection of an organic ligand with the appropriate functional groups which will be able to coordinate metal centers and form bridges among them. Huge numbers of carboxylic acids with aromatic, aliphatic or heterocyclic moieties are used as linkers in the lanthanide coordination polymers because of great affinity of carboxylate oxygen donor atoms for lanthanides. Particularly ligands containing more than one carboxylate group have drawn great interest due to more coordination sites and great tendency towards creation of multidimensional polymeric structures [16-34]. Besides benzenepolycarboxylic acids, which are regarded as the most explored linkers, multicarboxylic acids based on the rigid heterocyclic aromatic rings such as: pyridine, pyrazole, thiophene or furane are regarded as very attractive ligands in the formation of coordination polymers [35-40]. The presence of additional binding sites allows creating additional strong covalent bonds with metal ions resulting in the formation of novel extraordinary architectures with desired structural properties. On the other hand, the presence of extra electron pair on the donor atoms strongly influences on the intermolecular interactions and packing modes of molecules in the solid state. Taking into account the fact that the metal-organic frameworks are mainly considered as porous materials, such structural elements enhance compounds functionality [41, 42].

It is commonly known that structural and physicochemical properties of metal-organic are strongly dominated by synthetic procedures [43]. Despite the obvious influence of metal and linker precursors other factors such as: molar ratio of staring materials, solvent, $\mathrm{pH}$, temperature, reaction time, pressure or way of heating affect the final product. These parameters have a strong impact on their composition, structure, particle size and morphology [43-46]. Taking into account the reaction temperature and pressure, the MOF synthesis methods can be divided into the solvothermal and nonsolvothermal ones [46]. The solvothermal approach is the most effective in growing crystals of coordination polymers. In this liquid phase synthesis, the reaction proceeds under the autogenous pressure above the boiling point of the solvent for several hours or days using closed vessel. A Teflon-lined vessel is placed in a steel autoclave, in which the reagents are heated in high-boiling polar solvents, such as DMF, DEF, DMSO, $\mathrm{H}_{2} \mathrm{O}$, acetone, acetonitrile etc. The advantage of this method is that it ensures high solubility of the precursors and the formation of good quality MOF crystals suitable for structural investigations [46-49]. Among the nonsolvothermal methods of MOF synthesis, classical precipitation and mechanochemistry can be distinguished. A frequently used method of MOFs synthesis consists in the mixing the starting compounds (metal salt solution with the solution of organic ligand or its deprotonated form) at the appropriate stoichiometric ratio as a result of which a sparingly soluble precipitate is formed. After filtering the solution and drying the precipitate, MOF is obtained. The simplicity and mild temperature as well as pressure conditions are the advantages of such method [45, 46, 50-52]. The solvent-free mechanochemical method is the simplest, economical and environmentally friendly method compared to others in liquid phase syntheses. Currently this approach is used for the synthesis of MOF materials on a large scale. The synthesis consists in grinding appropriately selected substrates (a mixture of metal salts and organic ligands) in a ball mill. As a result of the supply of mechanical energy, intramolecular bonds are broken and new bonds are formed. The advantage of this method is avoiding organic solvents while the resulting by-products are harmless, and MOF can be obtained in a short reaction time [44]. In addition to the above characterized methods for the MOF synthesis, there are also other techniques with non-conventional heating, such as: microwave-assisted solvothermal, electrochemical or sonochemical methods. These methods replace the traditional solvothermal heating in the large-scale production of MOFs [53-55].

This publication is continuation of our long-term research on coordination polymers of lanthanides with polycarboxylic acids [37, 38, 47-50, 56-64]. Herein, the influence of different synthetic approaches on structural and thermal properties of the coordination polymers based on the selected lanthanide(III) ions such as: $\mathrm{Nd}(\mathrm{III}), \mathrm{Eu}(\mathrm{III}), \mathrm{Tb}(\mathrm{III})$ and $\operatorname{Er}(\mathrm{III})$ as well as 1H-pyrazole-3,5-dicarboxylic acid $\left(\mathrm{H}_{3} \mathrm{pdca}\right)$ is studied. Because the synthesized compounds are intended to be additives for luminescent polymeric composites, the selection of such ions was made due to their eminent light emission properties in the VIS and NIR regions. On the other hand, it is generally known that the decrease of coordination number in the series of lanthanide complexes is observed due to lanthanide contraction. This fact may imply structural diversity in the lanthanide series of complexes with the same ligand. Therefore, we have decided to select the representatives of light and heavy lanthanides for better understanding the relationship between the atomic number and the structure of compounds. The selection of $1 \mathrm{H}$-pyrazole-3,5-dicarboxylic acid (Scheme 1) was motivated by its excellent coordination abilities due to the presence of six potentially available coordinative sites after the deprotonation process of both carboxylic groups and the pyrazole ring [65]. This ligand forms both discrete and polymeric structures with s- and d- block elements [66-70] but the complexes with lanthanide ions are not well documented [71-73].

Regular studies of the impact of different synthesis conditions on the structure and properties of metal complexes are usually focused on a single method. Commonly the authors change one or more factors such as solvent, temperature or heating time that may affect the final product [46]. The study involving several completely different methods of complexes 


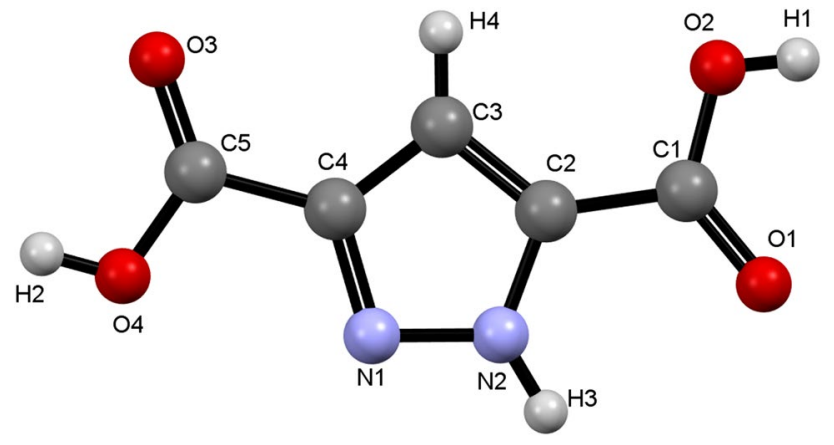

Scheme 1 Structure of $1 H$-pyrazole-3,5-dicarboxylic acid

synthesis concerning the same metal ions and linkers is still uncommon. Thus we decided to obtain coordination polymers using different synthesis methods as well as to determine the relationship between structure and properties of formed compounds. In particular, a lot of attention is paid to the determination of thermal properties of synthesized coordination polymers. As follows from literature data, the investigations on thermal behaviour of lanthanide coordination polymers based on the $1 H$-pyrazole-3,5-dicarboxylic acid are limited.

This paper presents our results concerning lanthanide coordination polymers obtained by different processing like hydrothermal, mechanochemical and classical precipitation procedures. Their composition and structural characteristics were determined by elemental analysis, ED-XRF, X-ray diffraction methods and infrared spectroscopy. Thermal behaviour of the complexes was examined by means of the TGDTG-DSC methods in air and the TG-FTIR method in the nitrogen atmosphere. The analysis of volatile products of decomposition of free linker and its lanthanide complexes allowed proposing their pyrolysis mechanisms.

\section{Experimental}

\subsection{Materials and Synthesis}

Monohydrate of $1 H$-pyrazole-3,5-dicarboxylic acid (98\%) and hydrates of lanthanide(III) nitrates(V) (99.9\%) were purchased from Alfa Aesar. All reagents were used without further purification.

The hydrothermal synthesis included two steps. In the first step deprotonation of $\mathrm{H}_{3}$ pdca acid was made using the $0.2 \mathrm{M} \mathrm{NaOH}$ solution. In the second stage the synthesis of complexes was carried out by mixing $\mathrm{Ln}\left(\mathrm{NO}_{3}\right)_{3}(1 \mathrm{mmol}, 20$ $\mathrm{ml}$ ) aqueous solutions (where $\mathrm{Ln}(\mathrm{III})=\mathrm{Nd}, \mathrm{Eu}, \mathrm{Tb}$ and $\mathrm{Er}$ ) with sodium salt of acid $(1.5 \mathrm{mmol}, 25 \mathrm{ml})$. The $\mathrm{pH}$ of the reaction mixture was 5 . The obtained mixtures were placed in the Teflon vessels and closed in the steel autoclaves. In order to achieve hydrothermal conditions, the synthesis proceeded at the temperature of $120^{\circ} \mathrm{C}$ for $72 \mathrm{~h}$. The autoclaves were allowed to cool to room temperature. The obtained suspensions were filtered and washed with distilled water. The europium(III) complex was obtained in the form of single-crystals while the remaining complexes were in the form of polycrystalline powders. The yield of hydrothermal synthesis was $76 \%$.

The mechanochemical synthesis consisted in grinding the appropriate mass of lanthanide(III) acetates $\mathrm{Ln}\left(\mathrm{CH}_{3} \mathrm{COO}\right)_{3} \cdot \mathrm{nH}_{2} \mathrm{O}(0.32 \mathrm{mmol})$, where $\mathrm{Ln}=\mathrm{Nd}, \mathrm{Eu}, \mathrm{Tb}$, Er and $\mathrm{H}_{3}$ pdca acid $(0.5 \mathrm{mmol})$ in the ball mill for $60 \mathrm{~min}$. Then the precipitates were washed with distilled water to remove the formed by-product i.e. acetic acid. The yield of mechanochemical synthesis was in the range 66-70\%. Milling was done using a RETSCH MM 400 mixing mill with the frequency of $30 \mathrm{~Hz}$, in $10 \mathrm{ml}$ crucibles and $5 \mathrm{~mm}$ diameter beads.

In the precipitation method, the stoichiometric amounts of the substrates were the same as in the hydrothermal method. After mixing the solutions containing appropriate amounts of lanthanide(III) nitrate(V) and the solution of sodium $1 \mathrm{H}$-pyrazole-3,5-dicarboxylate, the precipitates formed immediately were filtered, washed with water and placed for drying. The yield of the precipitation method synthesis was in the range $80-82 \%$.

\subsection{Methods}

The contents of $\mathrm{C}, \mathrm{H}$ and $\mathrm{N}$ in the obtained compounds were determined by the elemental analysis with a EuroEA Elemental Analyser and the results are given in Table A.1. The quantitative analysis of lanthanide elements in the complexes was performed using Energy-Dispersive X-Ray Spectrometer Canberra Packard (Table A.1). The infrared spectra (ATR-FTIR) of the acid and the obtained compounds were recorded using a Nicolet 6700 spectrophotometer equipped with the Smart iTR accessory (diamond crystal) in the range of $4000-600 \mathrm{~cm}^{-1}$. The X-ray powder diffraction patterns of the prepared complexes were made by means of a Empyrean powder diffractometer PANalytical using the Bragg-Brentano method.

Thermal analyses of the prepared complexes were made applying the thermogravimetric (TG) and differential scanning calorimetry (DSC) methods using the SETSYS 16/18 analyser (Setaram). The samples (about 5-9 mg) were heated in the alumina crucibles up to $1000^{\circ} \mathrm{C}$ at a heating rate of 10 ${ }^{\circ} \mathrm{C} \mathrm{min}{ }^{-1}$ in the dynamic air atmosphere $\left(\mathrm{v}=0.75 \mathrm{dm}^{3} \mathrm{~h}^{-1}\right)$.

Thermograms were recorded by TA Instruments Q5000 thermal analyzer heating the $20-30 \mathrm{mg}$ samples in the nitrogen flow atmosphere $\left(25 \mathrm{~cm}^{3} \mathrm{~min}^{-1}\right)$ at a heating rate of $20{ }^{\circ} \mathrm{C} \mathrm{min}^{-1}$. The samples were heated up to $700{ }^{\circ} \mathrm{C}$ in the open platinum crucibles. Gaseous products were recorded 
by a Nicolet 6700 spectrophotometer coupled with the thermobalance. The transfer line was heated up to $250{ }^{\circ} \mathrm{C}$ while the gas cell of spectrophotometer was heated up to $240{ }^{\circ} \mathrm{C}$.

Single-crystal diffraction data were collected at $293 \mathrm{~K}$ on an Oxford Diffraction Xcalibur CCD diffractometer with the graphite-monochromated $\mathrm{MoK}_{\mathrm{a}}$ radiation $(\lambda=0.71073$ $\AA)$. The programs CrysAlis CCD and CrysAlis Red [74] were used for data collection, cell refinement and data reduction. A multi-scan absorption correction was applied. The structures were solved by direct methods using SHELXS-97 [75] and refined by the full-matrix least squares on F2 using SHELXL-97 [75].

\section{Results and Discussion}

\subsection{General Characterization}

There were synthesized complexes with selected lanthanide ions i.e. $\mathrm{Nd}(\mathrm{III}), \mathrm{Eu}(\mathrm{III}), \mathrm{Tb}(\mathrm{III})$ and $\mathrm{Er}(\mathrm{III})$ with $1 H$-pyrazole-3,5-dicarboxylic acid of the general formula $\mathrm{Ln}_{2}(\mathrm{Hpdca})_{3} \cdot \mathrm{nH}_{2} \mathrm{O}$, where $\mathrm{Ln}=\mathrm{Nd}(\mathrm{III}), \mathrm{Eu}(\mathrm{III}), \mathrm{Tb}(\mathrm{III})$ and $\mathrm{Er}(\mathrm{III}) ; \mathrm{Hpdca}=\mathrm{C}_{5} \mathrm{H}_{2} \mathrm{~N}_{2} \mathrm{O}_{4}{ }^{2-}$ and $\mathrm{n}=6$ or 7 (Table A.1). The main purpose of our investigations was to determine influence of different synthetic procedures on the composition, structure and thermal properties of lanthanide coordination polymers. Besides the hydrothermal method (HT), which is commonly used in the synthesis of coordination polymers, mechanochemical (Mech) and classical precipitation approaches (Prep) were also applied.

Taking into account specificity of these methods, different metal precursors were used. Lanthanide(III) nitrates(V) were employed in the hydrothermal and precipitation methods while lanthanide(III) acetates were adapted in mechanochemistry. The application of lanthanide(III) acetate hydrate prevents formation of nitric acid as a by-product of mechanochemical reaction. This strong acid can dissolve the lanthanide complexes, which is an undesirable process during their synthesis. The use of lanthanide(III) acetate leads to the formation of acetic acid which, as a weak acid, does not dissolve the compounds formed in the solid state and can be easily removed by washing with water. The mechanochemical reactions were conducted under the solvent free conditions while water was used as a solvent of precursors in the hydrothermal and precipitation methods.

Taking into consideration the number of water molecules in the obtained complexes, all compounds prepared under the hydrothermal conditions comprise six water molecules exactly as it was observed in the previously reported complexes $[71,72]$. Six water molecules appear also in the complexes of $\mathrm{Tb}(\mathrm{III})$ synthesized by the other methods. The complexes of $\mathrm{Eu}(\mathrm{III})$ and $\operatorname{Er}(\mathrm{III})$ obtained by both the mechanochemical and precipitation manners exhibit seven water molecules similarly to the $\mathrm{Nd}$ (III) complex obtained in mechanochemistry. The presence of water molecules in the complexes obtained by the mechanically activated synthesis can be explained by using hydrates of lanthanide acetates.

\subsection{X-Ray Characterization}

All applied synthesis procedures result in the formation of polycrystalline materials as can be postulated from their diffractograms. It is worth noting that the XRD patterns of compounds obtained under the hydrothermal conditions show excellent quality (Fig. 1). Additionally, the hydrothermally prepared europium(III) complex has grown in the form of crystals suitable for single-crystal X-ray diffractions measurements. The XRD pattern generated from the single-crystal data of europium(III) complex corresponds well with the experimental one for the polycrystalline forms. Besides, the XRD pattern of the europium(III) complex is in good agreement with the diffractograms of all terbium(III) and erbium(III) complexes prepared by different methods. This statement allowed us to conclude that the complexes of $\mathrm{Eu}(\mathrm{III}), \mathrm{Tb}(\mathrm{III})$ and $\mathrm{Er}(\mathrm{III})$ are isomorphous in spite of the fact that some of them exhibit different numbers of water molecules (six or seven). Six water molecules appear in the inner coordination sphere of lanthanide(III) ions. An additional water molecule occupies free space in the metal-organic frameworks.

The single-crystal X-ray analysis reveals that the europium(III) complex crystallizes in the monoclinic $\mathrm{P} 2{ }_{1} / \mathrm{c}$ space group. The unit cell parameters are as follows: $a=10.9897(7) \AA, b=10.2103(5) \AA, c=10.5766(7)$ $\AA, \beta=100.149(5), V=1168.2(1) \AA^{3}, Z=4$ (Table A.2). These data are very similar to those of the 2D doubledecker coordination polymers reported previously (Fig. 2) [71, 72]. Taking this fact into account it can be concluded that the obtained isomorphous complexes of $\mathrm{Eu}(\mathrm{III})$, $\mathrm{Tb}$ (III) and $\mathrm{Er}(\mathrm{III})$ exhibit the same polymeric crystal structures. In the $\mathrm{Eu}_{2}(\mathrm{Hpdca})_{3} \cdot 6 \mathrm{H}_{2} \mathrm{O}$ complex, the eightcoordinated europium(III) atoms are coordinated by four $\mathrm{Hpdca}^{2-}$ ligands and three water molecules (Fig. 2a). The coordination environment of $\mathrm{Eu}(\mathrm{III})$ center consists from four carboxylate oxygen atoms, three oxygen atoms from aqua ligands and one nitrogen atom from pyrazole ring. The bond lengths Eu-O range from 2.343(7) to 2.465(8) $\AA$ while Eu-N is 2.519(7) $\AA$ (Table A.2). As can be seen in Fig. 2a, $1 H$-pyrazole-3,5-dicarboxylate linker behaves as tetradentate linker binding three different $\mathrm{Eu}(\mathrm{III})$ ions in bridgingchelating manner. Carboxylate groups adopt the bidentatebridging and monodentate modes.

However, the XRD patterns of neodymium(III) complexes obtained under various conditions differ from those of remaining complexes. The experimental XRD patterns of neodymium(III) complexes were also 

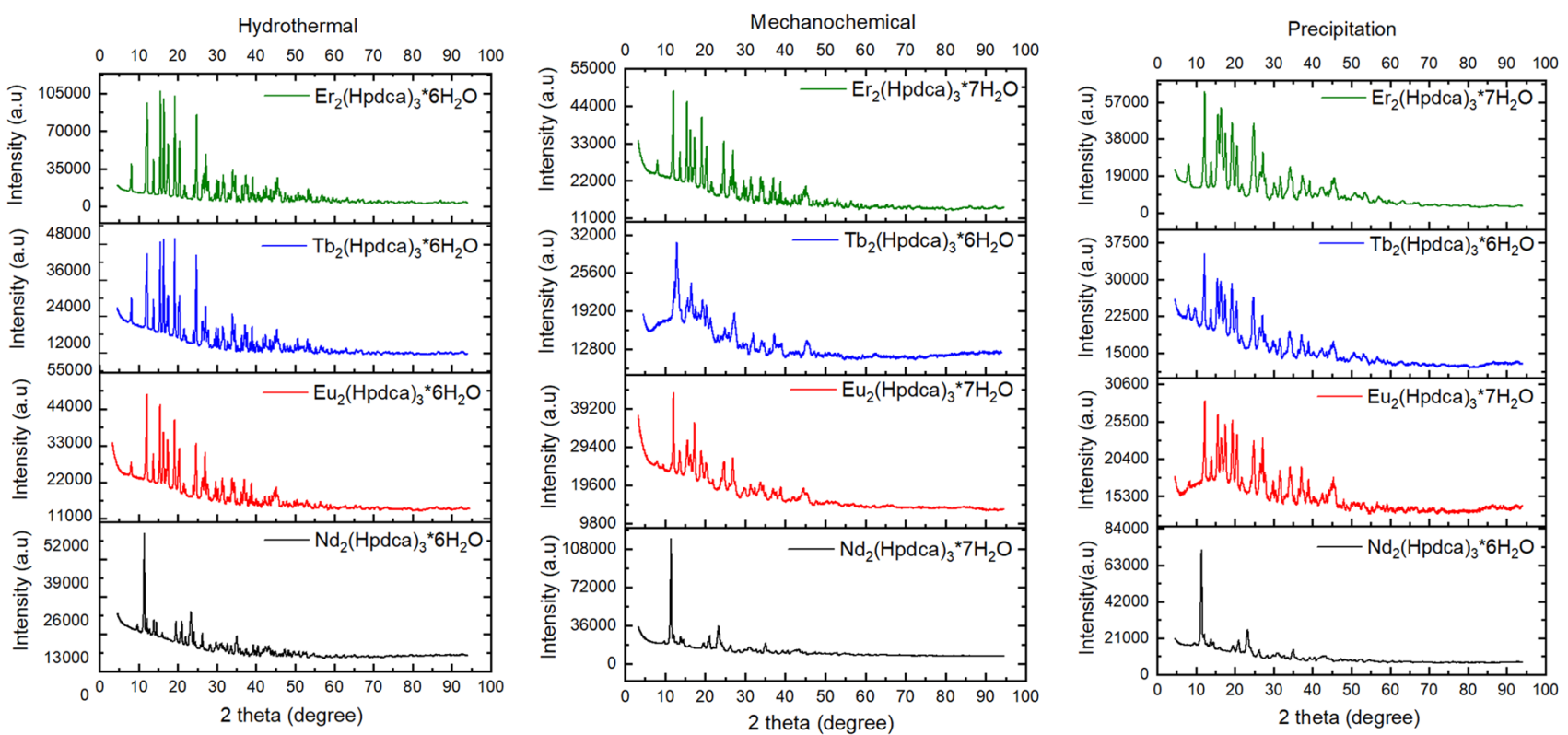

Fig. 1 X-ray diffraction patterns of lanthanide complexes synthesized by three different methods

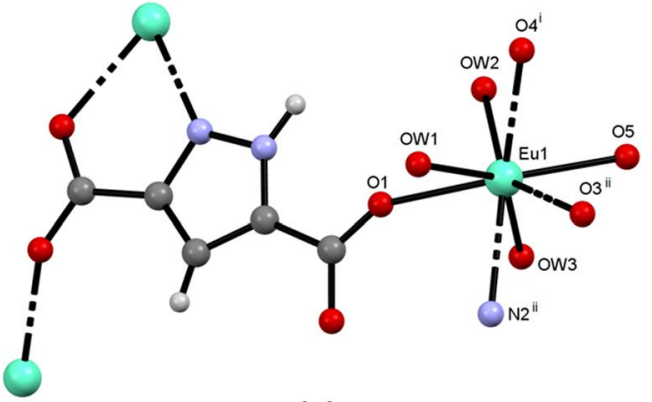

(a)

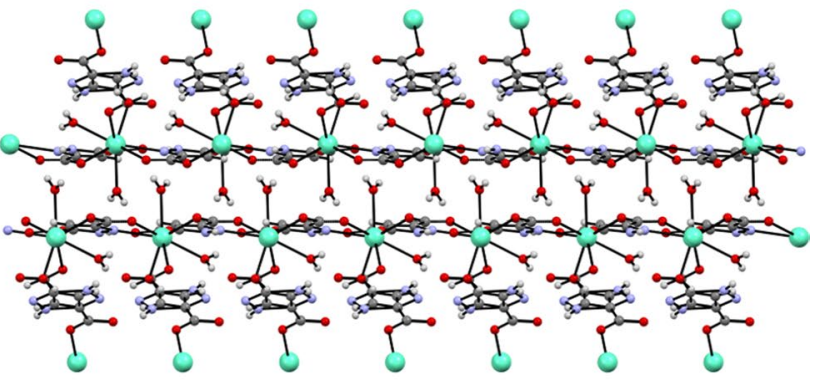

(b)

Fig. 2 a Central metal environment in $\mathrm{Eu}_{2}(\mathrm{Hpdca})_{3} \cdot 6 \mathrm{H}_{2} \mathrm{O}$ complex; b crystal packing of $\mathrm{Eu}_{2}(\mathrm{Hpdca})_{3} \cdot 6 \mathrm{H}_{2} \mathrm{O}$ complex in view along $b^{*}$ axis. symmetry codes: (i) $\mathrm{x}, \mathrm{y}+1, \mathrm{z}$; (ii) $\mathrm{x},-\mathrm{y}+0.5, \mathrm{z}-0.5$

compared with that calculated from the single-crystal data published by J. Xia and et. al [72]. The good agreement of such XRD patterns confirms that neodymium(III) complexes obtained by us are isomorphous with those threedimensional complexes reported in the literature. In such complexes, neodymium atoms are nine-coordinated being surrounded by both 1-H-pyrazole-3,5-dicarboxylate and aqua ligands. The organic ligands coordinate neodymium atoms through monodentate, bidentate-bridging and bidentate-chelating carboxylate groups and one nitrogen atom from the pyrazole moiety [72].

\subsection{Infrared Spectroscopy}

The determination of deprotonation degree of 1- $H$-pyrazole3,5-dicarboxylic acid in metal complexes was made based of the infrared spectra of free acid and its complexes (Fig. A.1).

This dicarboxylic acid belongs to the group of the ligands where besides deprotonation of $\mathrm{COOH}$ groups also aromatic ring can be deprotonated. The infrared spectrum of $\mathrm{H}_{3}$ pdca displays a relatively strong band at $3203 \mathrm{~cm}^{-1}$ assigned to the stretching vibrations of $\mathrm{OH}$ from the $\mathrm{COOH}$ groups as well as water molecules (monohydrate of acid was used in the syntheses). Broadening of such band indicates the 
presence of hydrogen bonds with participation of $\mathrm{OH}$ groups from $\mathrm{COOH}$. Additionally, the infrared spectrum of acid shows also a band at $3142 \mathrm{~cm}^{-1}$ derived from the stretching vibrations of $\mathrm{N}-\mathrm{H}$ group from the pyrazole ring. In the range $3000-2000 \mathrm{~cm}^{-1}$ bands associated with the stretching vibrations of $\mathrm{C}-\mathrm{H}$ groups and hydrogen bonds appear. The carboxylic groups give a very strong band at $1687 \mathrm{~cm}^{-1}$ assigned to the stretching vibrations of carbonyl groups $v(\mathrm{C}=\mathrm{O})$. The band at $1243 \mathrm{~cm}^{-1}$ was ascribed to the deformation vibrations of $\mathrm{C}-\mathrm{O}-\mathrm{H}$ moieties from the carboxylic groups. The several sharp bands at: 1557, 1489, 1445, 1392, 1317,1276 and $1204 \mathrm{~cm}^{-1}$ were attributed to the stretching and bending vibrations of the pyrazole ring [76-78].

The ATR-FTIR spectra of all investigated lanthanide complexes show clearly the presence of water molecules in their structures (Fig. A.2). In the wavenumber range $3500-2400 \mathrm{~cm}^{-1}$ the infrared spectra exhibit a broad band assigned to the stretching vibrations of $\mathrm{O}-\mathrm{H}$ groups from the water molecules which take part in the hydrogen bonds. Additionally, in the above mentioned region, a weak sharp band with the maximum in the range $3134-3130 \mathrm{~cm}^{-1}$ is observed (complexes of $\mathrm{Eu}, \mathrm{Tb}$ and $\mathrm{Er}$ ) due to stretching vibrations of $\mathrm{N}-\mathrm{H}$ group from the pyrazole ring [76-78]. This band is slightly shifted towards the lower wavenumber compared with its position in the free acid. This can be explained in terms of changes in the electron density on the ring atoms as a result of metal coordination through the carboxylate groups and nitrogen atom (position 2 in the pyrazole ring). Interestingly, in the neodymium complexes the stretching vibrations of $\mathrm{N}-\mathrm{H}$ group appear in the similar position $\left(3146 \mathrm{~cm}^{-1}\right)$ to that of the free acid. This observation confirms the structural diversity between neodymium and other complexes.

The characteristic bands from the carboxylic groups disappeared in the infrared spectra of metal complexes. On the other hand, new very diagnostic bands from the carboxylate groups are observed on the spectra of all complexes which is indicative of deprotonation of $\mathrm{COOH}$ groups and metal ions coordination. In the spectra of isomorphous complexes $(\mathrm{Eu}, \mathrm{Tb}$ and $\mathrm{Er})$, asymmetric and symmetric stretching vibrations of carboxylate groups appear in the ranges: 1597-1579 and $1359-1348 \mathrm{~cm}^{-1}$, respectively [56-64]. A very similar position of bands derived from stretching vibrations of carboxylate groups suggests the same coordination modes of $\mathrm{COO}$ groups in the $\mathrm{Eu}, \mathrm{Tb}$ and $\mathrm{Er}$ complexes. However, the ATR-FTIR spectra of neodymium complexes show very similar wavenumbers of stretching asymmetric vibrations of carboxylate groups $\left(1589-1586 \mathrm{~cm}^{-1}\right)$ whereas the symmetric stretching vibrations of $\mathrm{COO}$ are shifted towards lower $\left(1312 \mathrm{~cm}^{-1}\right)$ wavenumbers compared to the remaining complexes. This fact points out to different coordination behaviour of carboxylate groups in the $1 \mathrm{H}$-pyrazole-3,5-dicarboxylate ligands in the $\mathrm{Nd}$ complexes. This conclusion is in good agreement with the above statement about the coordination mode of $1 \mathrm{H}$-pyrazole-3,5-dicarboxylate linker in the obtained $\mathrm{Nd}$ complexes [72].

\subsection{Thermal Analysis in Air}

Thermal behaviour of free $1 H$-pyrazole-3,5-dicarboxylic acid as well as the investigated lanthanide coordination polymers was studied by the TG, DTG and DSC methods in the air atmosphere (Fig. 3). The $1 H$-pyrazole-3,5-dicarboxylic acid is thermally sustained up to $92^{\circ} \mathrm{C}$. Further heating leads to the dehydration process in the range $93-140{ }^{\circ} \mathrm{C}$ connected with the mass loss of $10.07 \%$ corresponding to the release of one water molecule (calc. mass loss of $10.34 \%$ ). This step is accompanied by the endothermic effect (onset point: $103^{\circ} \mathrm{C}$, peak top at $122{ }^{\circ} \mathrm{C}$ ) with the value of dehydration enthalpy of $49.14 \mathrm{~kJ} / \mathrm{mol}$. In the temperature range of $141-260{ }^{\circ} \mathrm{C}$ a plateau on the TG curve of the acid dehydrated form is observed. Above $212^{\circ} \mathrm{C}$, some structural transformations in the solid state take place as can be postulated from the presence of very weak endothermic effects on the DSC curve. At a higher temperature, melting and decomposition processes occur with the significant mass loss of $83 \%$. Above processes are accompanied by the endothermic effect with the peak top at $297{ }^{\circ} \mathrm{C}$ (onset point: $293{ }^{\circ} \mathrm{C}$ ) with the value of enthalpy of $73.40 \mathrm{~kJ} / \mathrm{mol}$. Above $318^{\circ} \mathrm{C}$, some solid residue (about $7 \%$ ) appears. During further heating, this residue is burnt up to $640{ }^{\circ} \mathrm{C}$. This process is accompanied by the exothermic effect on the DSC curve.

The recorded thermoanalytical curves of the complexes obtained by different methods are given in Figs. 4, 5, 6, 7 and 8 . The results from the thermal analysis made in the air atmosphere are summarized in Table 1 . The metal complexes obtained under the hydrothermal conditions show the

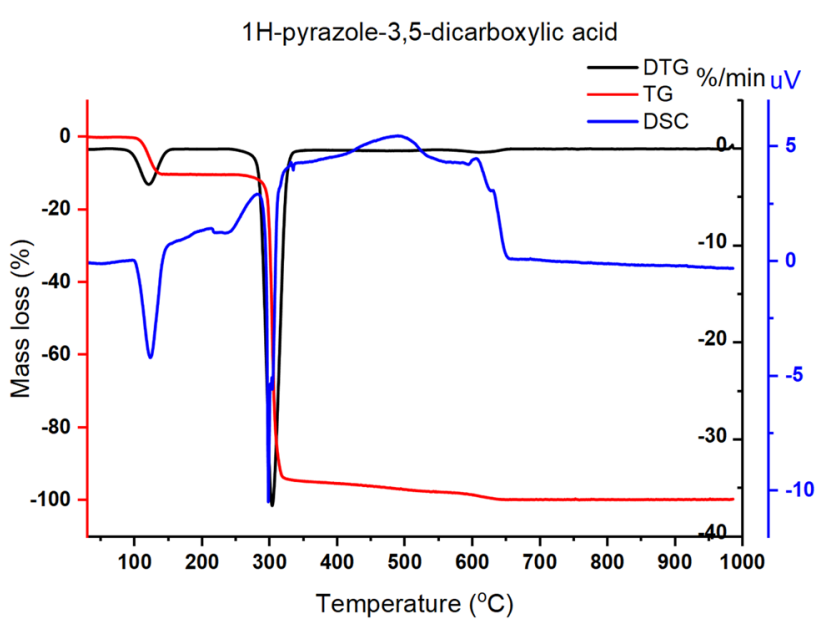

Fig. 3 TG, DTG and DSC curves of free 1H-pyrazole-3,5-dicarboxylic acid in air atmosphere 

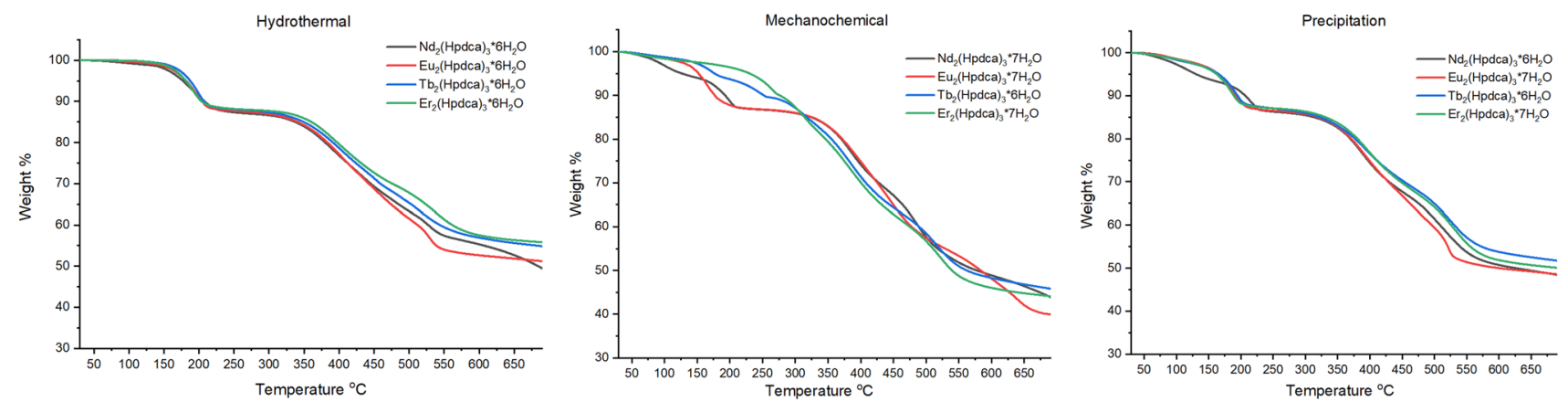

Fig. 4 TG curves of investigated lanthanide complexes in nitrogen atmosphere
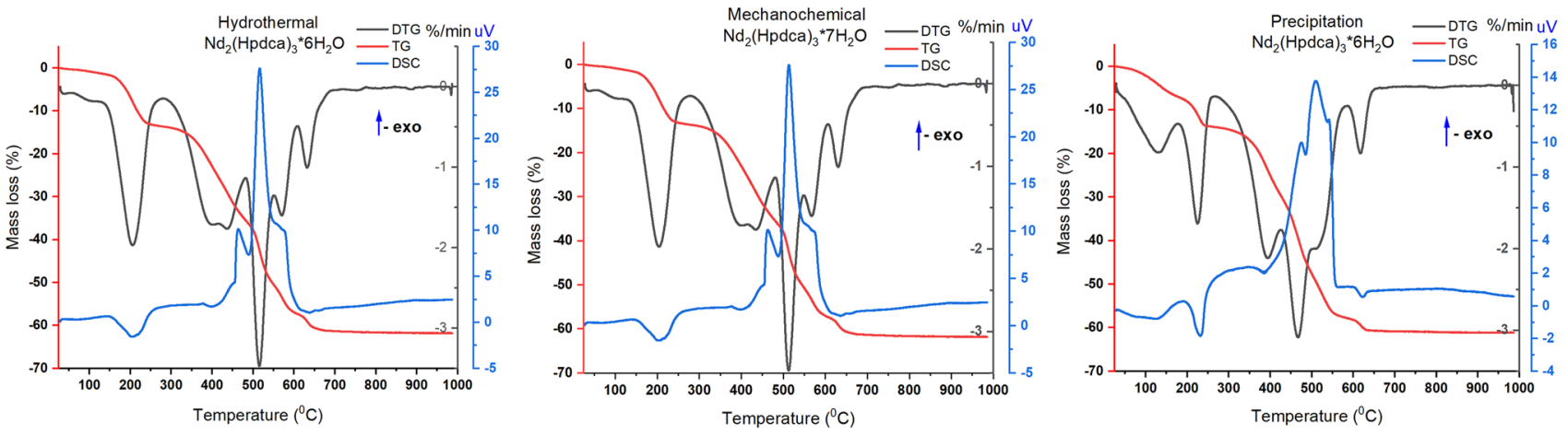

Fig. 5 TG, DTG and DSC curves of $\mathrm{Nd}_{2}(\mathrm{Hpdca})_{3} \cdot \mathrm{nH}_{2} \mathrm{O}$ complexes in air atmosphere
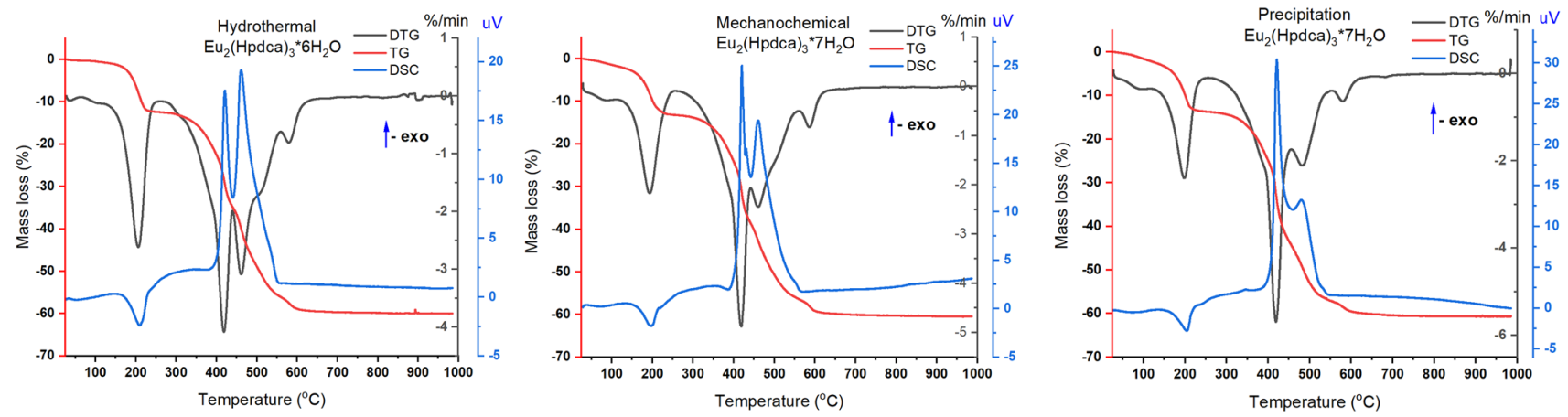

Fig. 6 TG, DTG and DSC curves of $\mathrm{Eu}_{2}(\mathrm{Hpdca})_{3} \cdot \mathrm{nH}_{2} \mathrm{O}$ complexes in air atmosphere

highest thermal stability. The complexes of $\mathrm{Eu}(\mathrm{III}), \mathrm{Tb}(\mathrm{III})$ and $\mathrm{Er}(\mathrm{III})$ are stable up to 88,115 and $81{ }^{\circ} \mathrm{C}$, respectively. The hydrothermally prepared $\mathrm{Nd}(\mathrm{III})$ complex as well as the other compounds synthesized by the mechanochemistry and precipitation methods are stable only up to $30^{\circ} \mathrm{C}$. Heating of the complexes results in the removal of water molecules which takes place in the temperature range 30-268 ${ }^{\circ} \mathrm{C}$. The recorded mass losses given in Table 1 correspond to the release of six or seven water molecules. From the shapes of TG, DTG and DSC curves it can be stated that the dehydration process in the complexes obtained under the hydrothermal conditions occurs in one step. On the other hand, in the metal complexes prepared by the alternative methods, the loss of water molecules proceeds in two hardly distinguishable stages in the wider temperature range.

Taking into account the characteristics of endothermic effects associated with the water molecules release during dehydration some observations were made. Considering the values of enthalpy of dehydration process in the series of complexes with the same metal ion, the highest value 

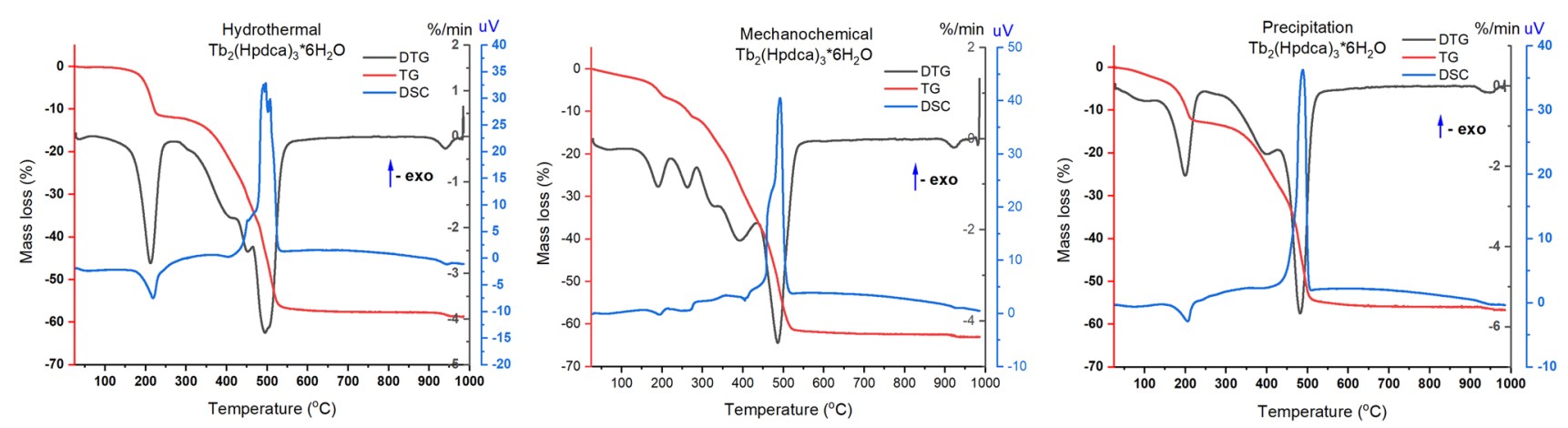

Fig. 7 TG, DTG and DSC curves of $\mathrm{Tb}_{2}(\mathrm{Hpdca})_{3} \cdot \mathrm{nH}_{2} \mathrm{O}$ complexes in air atmosphere
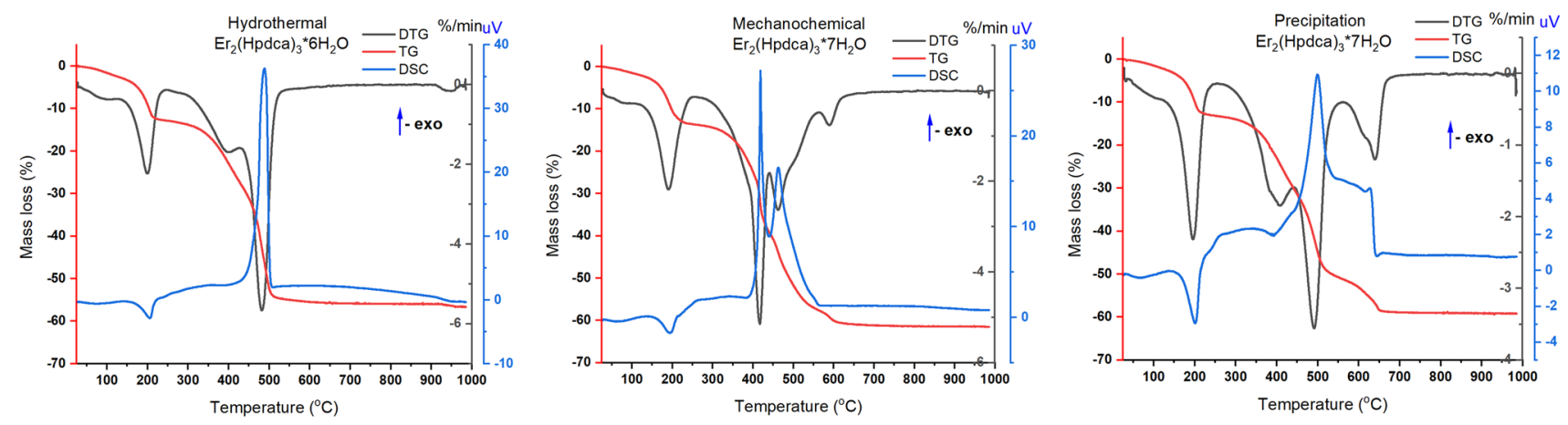

Fig. 8 TG, DTG and DSC curves of $\mathrm{Er}_{2}(\mathrm{Hpdca})_{3} \cdot \mathrm{nH}_{2} \mathrm{O}$ complexes in air atmosphere

is found for the complex prepared under the hydrothermal conditions $(261-335 \mathrm{~kJ} / \mathrm{mol})$. The lowest values of endothermic effect associated with the dehydration process were recorded for the complexes synthesized by precipitation method (154-239 kJ/mol). These observations can be explained based on different energy delivery methods during the complexes synthesis. The hydrothermal approach is characterized by heating under the autogenous pressure for a long period of time which results in the formation of crystals. The structures are largely ordered and removal of strongly bound water molecules requires more energy. On the other hand, in mechanochemistry and precipitation method, a relatively short period of time of energy input is not sufficient for formation of highly crystalline compounds in which water molecules are very tightly bound.

As can be seen from the TG curves and data given in Table 1, the dehydrated forms of complexes are unstable. Removal of coordinated water molecules from the structures of investigated compounds leads to the collapse of metal-organic frameworks and their decomposition. This process begins in the temperature range $241-272{ }^{\circ} \mathrm{C}$. Above such temperature, decomposition along with burning of organic fragments of compounds in the overlapping steps takes place. These processes are accompanied by strong exothermic effects. In the case of terbium complexes, above
$530{ }^{\circ} \mathrm{C}$ some intermediate solid products are formed which is most probably $\mathrm{Tb}_{2}\left(\mathrm{CO}_{3}\right)_{3}$. This compound is thermally stable up to $930{ }^{\circ} \mathrm{C}$ and then transforms into $\mathrm{Tb}_{4} \mathrm{O}_{7}[49,50$, $56,58]$.

\subsection{Identification of Gaseous Products of Free Ligand and Complexes Decomposition}

The TG-FTIR technique was employed to determine pyrolysis mechanisms of the hydrothermally synthesized complexes in the nitrogen atmosphere. The analysis of gaseous products of thermal decomposition of the prepared complexes allows for better understanding their thermal behaviour in the inert atmosphere and identification of decomposition products. Among others, it allows to determine the presence of water molecules in the complex structures and the stability of metal-ligand bonds. First of all, thermal decomposition of free $1 \mathrm{H}$-pyrazole-3,5-dicarboxylic acid was examined and the volatile products of its degradation were identified based on their FT-IR spectra. As can be deduced from the recorded infrared spectra of evolved gases (Figs. 9 and 10, Fig. A.3, Table 2), decomposition of free acid occurs in three main stages: (1) dehydration process, (2) decarboxylation process and (3) pyrazole volatilization. During heating of ligand in the nitrogen, water 
Table 1 Data from thermal analysis of prepared complexes recorded in air atmosphere

\begin{tabular}{|c|c|c|c|c|c|c|c|c|c|}
\hline & \multirow[t]{2}{*}{$\Delta \mathrm{T}_{1}\left({ }^{\circ} \mathrm{C}\right)$} & \multicolumn{2}{|c|}{ Mass loss (\%) } & \multirow[t]{2}{*}{$\Delta \mathrm{T}_{2}\left({ }^{\circ} \mathrm{C}\right)$} & \multicolumn{2}{|c|}{ Mass loss $(\%)$} & \multirow[t]{2}{*}{$\Delta \mathrm{H}(\mathrm{kJ} / \mathrm{mol})$} & \multirow[t]{2}{*}{ Onset point $\left({ }^{\circ} \mathrm{C}\right)$} & \multirow[t]{2}{*}{ Peak top $\left({ }^{\circ} \mathrm{C}\right)$} \\
\hline & & Found & Calc & & Found & Calc & & & \\
\hline \multicolumn{10}{|c|}{$\begin{array}{l}\text { Hydrothermally obtained } \\
\text { complexes }\end{array}$} \\
\hline $\mathrm{Nd}_{2}(\mathrm{Hpdca})_{3} \cdot 6 \mathrm{H}_{2} \mathrm{O}$ & $30-262$ & 13.03 & 12.57 & $272-730$ & 60.85 & 60.81 & 331.438 & 160.73 & 204.13 \\
\hline $\mathrm{Eu}_{2}(\mathrm{Hpdca})_{3} \cdot 6 \mathrm{H}_{2} \mathrm{O}$ & $88-228$ & 11.77 & 12.36 & $245-780$ & 59.96 & 59.72 & 261.446 & 175.03 & 209.73 \\
\hline $\mathrm{Tb}_{2}(\mathrm{Hpdca})_{3} \cdot 6 \mathrm{H}_{2} \mathrm{O}$ & $115-242$ & 11.76 & 12.65 & 264-948* & 60.51 & 57.92 & 335.683 & 184.81 & 217.91 \\
\hline $\mathrm{Er}_{2}(\mathrm{Hpdca})_{3} \cdot 6 \mathrm{H}_{2} \mathrm{O}$ & $81-243$ & 11.63 & 11.93 & $257-727$ & 57.73 & 57.76 & 263.47 & 173.88 & 206.3 \\
\hline \multicolumn{10}{|c|}{$\begin{array}{l}\text { Mechanochemically obtained } \\
\text { complexes }\end{array}$} \\
\hline $\mathrm{Nd}_{2}(\mathrm{Hpdca})_{3} \cdot 7 \mathrm{H}_{2} \mathrm{O}$ & $30-246$ & 14.21 & 14.37 & $256-762$ & 62.03 & 61.62 & 186.071 & 203.18 & 230.42 \\
\hline $\mathrm{Eu}_{2}(\mathrm{Hpdca})_{3} \cdot 7 \mathrm{H}_{2} \mathrm{O}$ & $30-242$ & 13.58 & 14.12 & $259-675$ & 60.58 & 60.55 & 259.823 & 165.89 & 199.42 \\
\hline $\mathrm{Tb}_{2}(\mathrm{Hpdca})_{3} \cdot 6 \mathrm{H}_{2} \mathrm{O}$ & $30-268$ & 11.61 & 11.93 & $270-598$ & 61.91 & 60.05 & 219.89 & 170.75 & 195.01 \\
\hline $\mathrm{Er}_{2}(\mathrm{Hpdca})_{3} \cdot 7 \mathrm{H}_{2} \mathrm{O}$ & $30-243$ & 13.16 & 12.69 & $260-679$ & 61.07 & 61.47 & 307.309 & 159.78 & 194.42 \\
\hline \multicolumn{10}{|l|}{$\begin{array}{l}\text { Precipitated } \\
\text { complexes }\end{array}$} \\
\hline $\mathrm{Nd}_{2}(\mathrm{Hpdca})_{3} \cdot 6 \mathrm{H}_{2} \mathrm{O}$ & $30-246$ & 13.65 & 12.57 & $263-660$ & 60.72 & 60.82 & 154.869 & 204.57 & 230.79 \\
\hline $\mathrm{Eu}_{2}(\mathrm{Hpdca})_{3} \cdot 7 \mathrm{H}_{2} \mathrm{O}$ & $30-241$ & 13.58 & 13.65 & $252-701$ & 60.39 & 58.52 & 222.807 & 167.65 & 204.08 \\
\hline $\mathrm{Tb}_{2}(\mathrm{Hpdca})_{3} \cdot 6 \mathrm{H}_{2} \mathrm{O}$ & $30-232$ & 12.64 & 11.93 & $241-671$ & 55.78 & 54.38 & 203.051 & 172.01 & 205.21 \\
\hline $\mathrm{Er}_{2}(\mathrm{Hpdca})_{3} \cdot 7 \mathrm{H}_{2} \mathrm{O}$ & $30-234$ & 12.95 & 13.65 & $242-672$ & 58.75 & 58.55 & 239.522 & 167.26 & 201.28 \\
\hline
\end{tabular}

$\Delta \mathrm{T}_{1}$ - temperature range of dehydration process

$\Delta \mathrm{T}_{2}$ - temperature range of $\mathrm{Ln}_{2}(\mathrm{Hpdca})_{3}$ decomposition

$\Delta \mathrm{H}$ - value of enthalpy of dehydration process

Peak top-temperature of maximum in endothermic peak

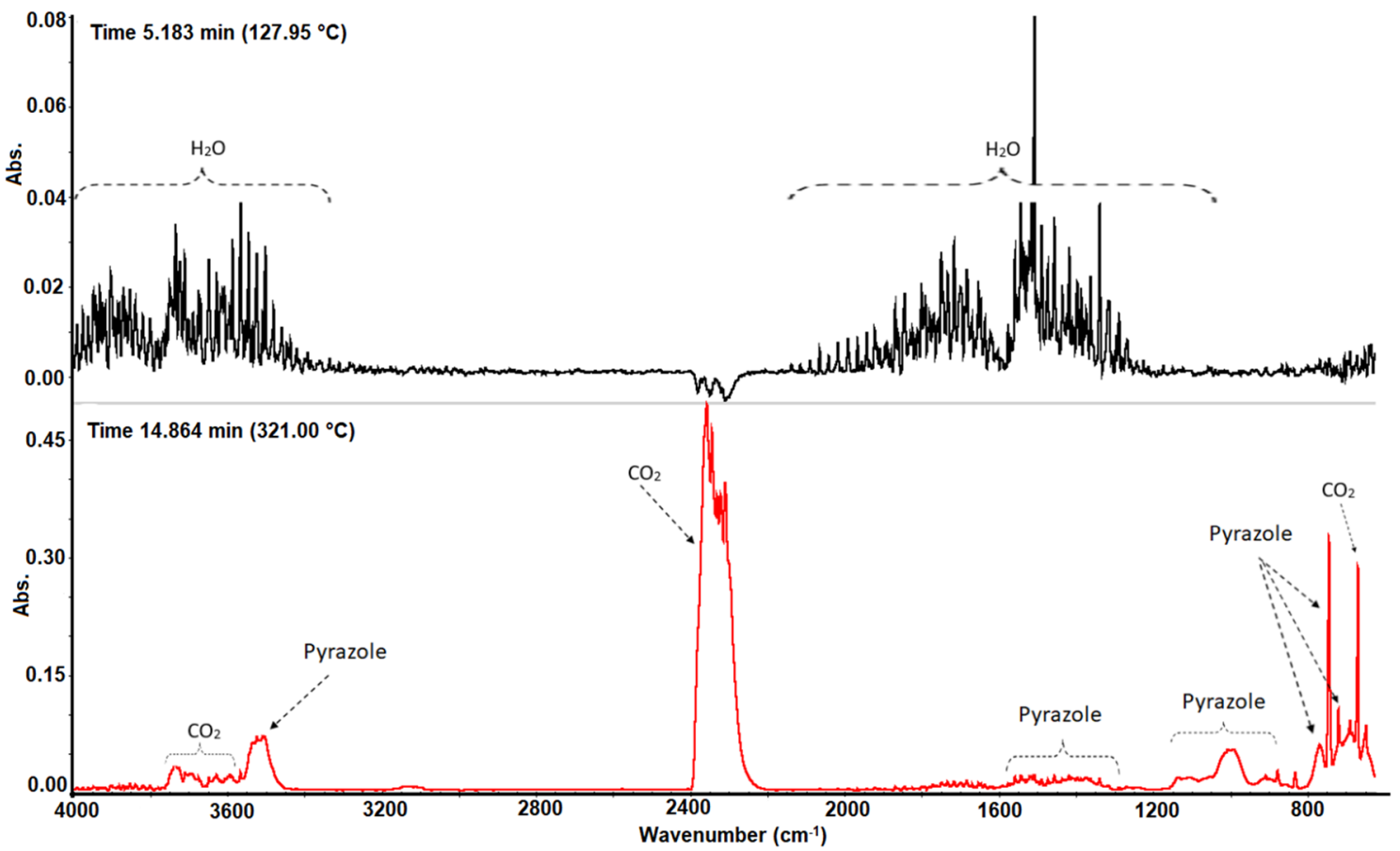

Fig. 9 The FTIR spectra of gaseous products of 1H-pyrazole-3,5-dicarboxylic acid decomposition (nitrogen atmosphere) 


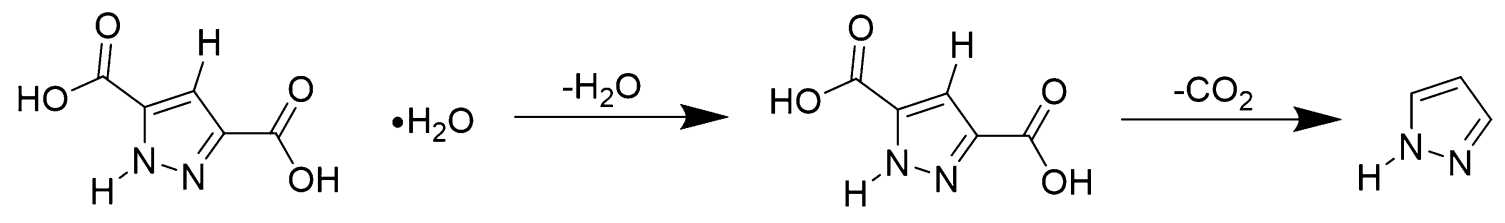

Fig. 10 Decomposition mechanism of 1H-pyrazole-3,5-dicarboxylic acid monohydrate

Table 2 The time and temperature ranges of the release of the main gaseous products of thermal decomposition of the synthesized complexes

\begin{tabular}{|c|c|c|c|c|c|}
\hline $\begin{array}{l}\text { Complex/gaseous } \\
\text { product }\end{array}$ & $\mathrm{H}_{3}$ pdca & $\mathrm{Nd}_{2}(\mathrm{Hpdca})_{3} \cdot 6 \mathrm{H}_{2} \mathrm{O}$ & $\mathrm{Eu}_{2}(\mathrm{Hpdca})_{3} \cdot 6 \mathrm{H}_{2} \mathrm{O}$ & $\mathrm{Tb}_{2}(\mathrm{Hpdca})_{3} \cdot 6 \mathrm{H}_{2} \mathrm{O}$ & $\mathrm{Er}_{2}(\mathrm{Hpdca})_{3} \cdot 6 \mathrm{H} 2 \mathrm{O}$ \\
\hline $\mathrm{H}_{2} \mathrm{O}$ & $\begin{array}{l}3.9-10 \min (102.74- \\
\left.220.78^{\circ} \mathrm{C}\right)\end{array}$ & $\begin{array}{l}2-16 \min (62.16- \\
\left.340.67^{\circ} \mathrm{C}\right)\end{array}$ & $\begin{array}{l}\text { 3-14 } \min (87.37- \\
\left.303.78^{\circ} \mathrm{C}\right)\end{array}$ & $\begin{array}{c}3-13 \min (87.37- \\
\left.286.57^{\circ} \mathrm{C}\right)\end{array}$ & $\begin{array}{l}3-13 \min (87.37- \\
\left.286.57^{\circ} \mathrm{C}\right)\end{array}$ \\
\hline $\mathrm{CO}_{2}$ & $\begin{array}{l}11.9-30 \min (261.98- \\
\left.626.65^{\circ} \mathrm{C}\right)\end{array}$ & $\begin{array}{l}10-30 \min (220.78- \\
\left.625.65^{\circ} \mathrm{C}\right)\end{array}$ & $\begin{array}{l}12-30 \min (266.89- \\
\left.626.56{ }^{\circ} \mathrm{C}\right)\end{array}$ & $\begin{array}{l}12-30 \min (266.89- \\
\left.626.56^{\circ} \mathrm{C}\right)\end{array}$ & $\begin{array}{l}12-30 \min (266.89- \\
\left.626.56^{\circ} \mathrm{C}\right)\end{array}$ \\
\hline Pyrazole $\left(\mathrm{C}_{3} \mathrm{H}_{4} \mathrm{~N}_{2}\right)$ & $\begin{array}{l}14-26 \min (303.78- \\
\left.544.17^{\circ} \mathrm{C}\right)\end{array}$ & - & $\begin{array}{l}18-21 \min (386.78- \\
\left.446.42^{\circ} \mathrm{C}\right)\end{array}$ & $\begin{array}{l}18-22 \min (386.78- \\
\left.466.09^{\circ} \mathrm{C}\right)\end{array}$ & $\begin{array}{l}18-21 \min (386.78- \\
\left.446.42^{\circ} \mathrm{C}\right)\end{array}$ \\
\hline $\begin{array}{l}\text { Hydrogen cyanide } \\
\text { (HCN) }\end{array}$ & - & - & $\begin{array}{l}22-30 \mathrm{~min}(466.09- \\
\left.626.56^{\circ} \mathrm{C}\right)\end{array}$ & $\begin{array}{l}22-30 \min (466.09- \\
\left.626.56^{\circ} \mathrm{C}\right)\end{array}$ & $\begin{array}{l}21-32 \min (446.42- \\
\left.667.13^{\circ} \mathrm{C}\right)\end{array}$ \\
\hline Hydrazine $\left(\mathrm{N}_{2} \mathrm{H}_{4}\right)$ & - & - & $\begin{array}{l}28-30 \min (585.98- \\
\left.626.65^{\circ} \mathrm{C}\right)\end{array}$ & $\begin{array}{l}27-30 \min (566.3- \\
\left.626.56^{\circ} \mathrm{C}\right)\end{array}$ & $\begin{array}{l}28-32 \min (585.98- \\
\left.667.13^{\circ} \mathrm{C}\right)\end{array}$ \\
\hline Ammonia $\left(\mathrm{NH}_{3}\right)$ & - & - & $\begin{array}{l}28-30 \min (585.98- \\
\left.626.65^{\circ} \mathrm{C}\right)\end{array}$ & $\begin{array}{l}27-30 \min (566.3- \\
\left.626.56^{\circ} \mathrm{C}\right)\end{array}$ & $\begin{array}{l}28-32 \min (585.98- \\
\left.667.13^{\circ} \mathrm{C}\right)\end{array}$ \\
\hline $\begin{array}{l}\text { Aliphatic Isocyanate } \\
\text { (RNCO) }\end{array}$ & - & $\begin{array}{l}22-28 \min (446.09- \\
\left.585.98^{\circ} \mathrm{C}\right)\end{array}$ & $\begin{array}{l}25-28 \min (525.73- \\
\left.585.98^{\circ} \mathrm{C}\right)\end{array}$ & $\begin{array}{l}25-28 \min (525.73- \\
\left.585.98^{\circ} \mathrm{C}\right)\end{array}$ & $\begin{array}{l}25-28 \min (525.73- \\
\left.585.98^{\circ} \mathrm{C}\right)\end{array}$ \\
\hline
\end{tabular}

molecules are released at first. They give very diagnostic sharp bands in the wavenumber ranges of 3900-3000 and $1800-1300 \mathrm{~cm}^{-1}$ attributed to the stretching and deformation vibrations of $\mathrm{OH}$ groups (Figs. 9 and 10). The water molecules release is observed during the time from 3.9 $\min$ to $8 \mathrm{~min}$ (Table 2), which is related to the temperature range $102.74-220.78{ }^{\circ} \mathrm{C}$. The dehydrated form of acid is temporarily thermally stable up to $238^{\circ} \mathrm{C}$. The next stage of ligand degradation is connected with the decarboxylation process during which carbon dioxide $\left(\mathrm{CO}_{2}\right)$ molecules are released. Strong, well-defined absorption bands in the region $2400-2200 \mathrm{~cm}^{-1}$ as well as those at $699 \mathrm{~cm}^{-1}$ are associated with the stretching and deformation vibrations of $\mathrm{CO}_{2}[79,80]$. The evolution of carbon dioxide molecules takes place from $11.9\left(261.98^{\circ} \mathrm{C}\right)$ minute and lasts $30 \mathrm{~min}$ (up to $626.65^{\circ} \mathrm{C}$ ) until the end of decomposition. During the decarboxylation process, free pyrazole molecules are produced, which are observed in the volatile decomposition products. Pyrazole molecules are evolved from 14 to 26 min of decomposition, in the temperature range $303.78-544.17^{\circ} \mathrm{C}$. Broad absorption bands in the wavenumber ranges of $3600-400,1500-1350 \mathrm{~cm}^{-1}$ as well as sharp absorption bands at 775,750 and $725 \mathrm{~cm}^{-1}$ were assigned to the stretching modes of $\mathrm{NH}$ and $\mathrm{CH}$ groups, skeletal bands and $\mathrm{CH}$ out-of-plane bending vibrations of pyrazole molecules, respectively [78, 81].
The FTIR spectra of evolved gaseous products during the thermal decomposition in the $\mathrm{N}_{2}$ atmosphere of the prepared complexes are shown in Figs. 11, 12, 13 and 14, Figures A.3-A.7 and Table 2. The proposed mechanism of complex decomposition in the nitrogen atmosphere is given in Fig. 15. Water molecules release takes place for all metal complexes as indicated by the presence of stretching and deformation modes of $\mathrm{OH}$ groups in the ranges $4000-3000$ and $2000-1300 \mathrm{~cm}^{-1}$, respectively. The neodymium complex exhibits the lowest thermal stability and liberated water molecules are observed above 62 ${ }^{\circ} \mathrm{C}$ while in the case of other complexes above $87{ }^{\circ} \mathrm{C}$. The most intense evolution of water molecules due to the dehydration process is observed in the range of 2-16 $\mathrm{min}$, which is related to the temperature range of 62.16-340.67 ${ }^{\circ} \mathrm{C}$. Further heating of unstable products of dehydration results in the decomposition process connected with mass losses observed on the TG curves. At first, the decarboxylation process of the investigated complexes takes place as a result of breaking $\mathrm{Ln}-\mathrm{O}_{\text {carb. }}$ and pyrazole$\mathrm{COO}$ bonds. The evolution of carbon dioxide molecules is noticed. The characteristic bands derived from $\mathrm{CO}_{2}$ (bands in the region $2400-2200 \mathrm{~cm}^{-1}$ and below 800 $\mathrm{cm}^{-1}$ ) were observed from $220.78{ }^{\circ} \mathrm{C}$ for the $\mathrm{Nd}$ complex (from $266{ }^{\circ} \mathrm{C}$ for the other complexes) almost up to the end of all experiments. Taking into account the fact 


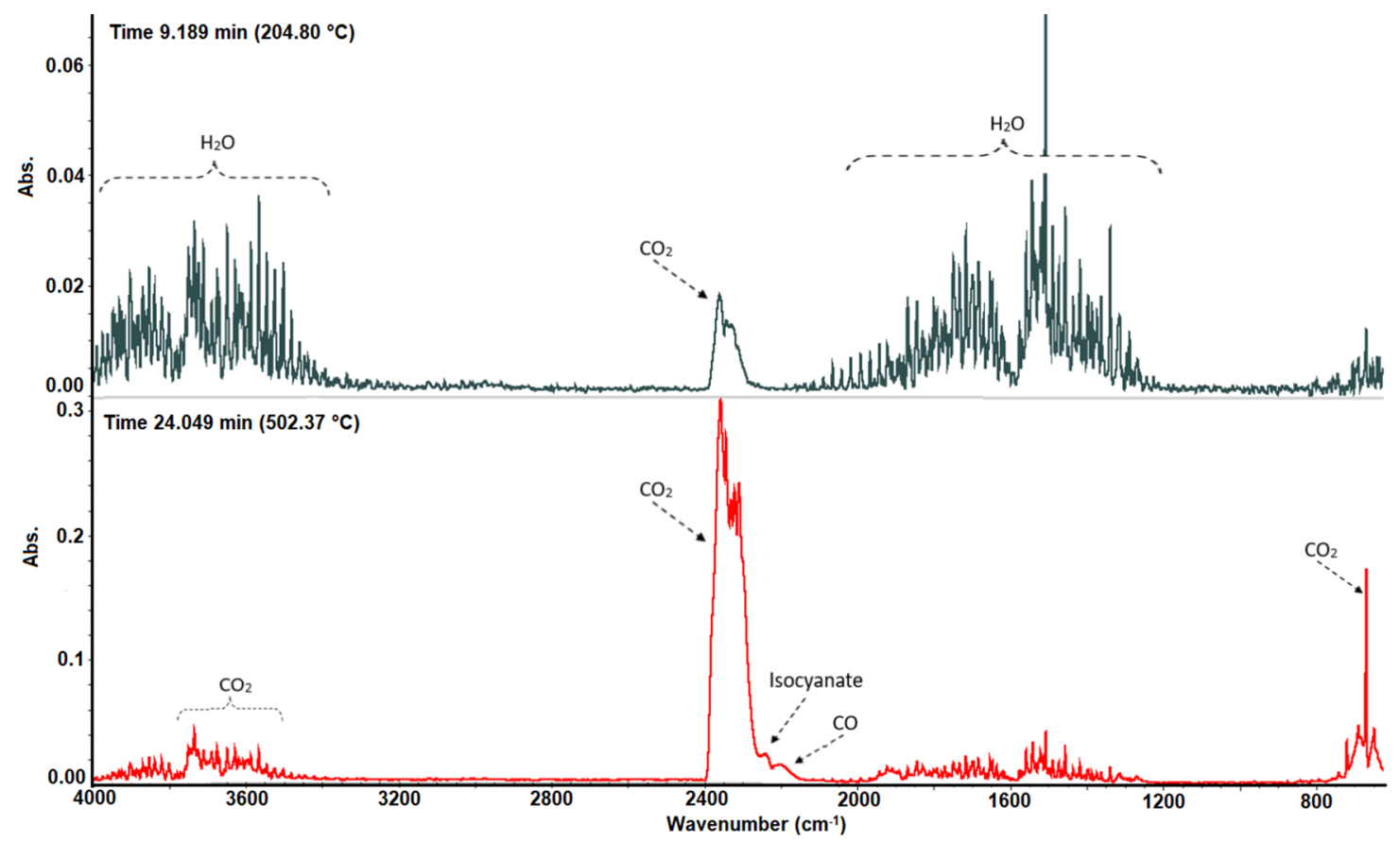

Fig. 11 The FTIR spectra of volatile products of $\mathrm{Nd}_{2}(\mathrm{Hpdca})_{3} \cdot 6 \mathrm{H}_{2} \mathrm{O}$ complex decomposition (nitrogen atmosphere)

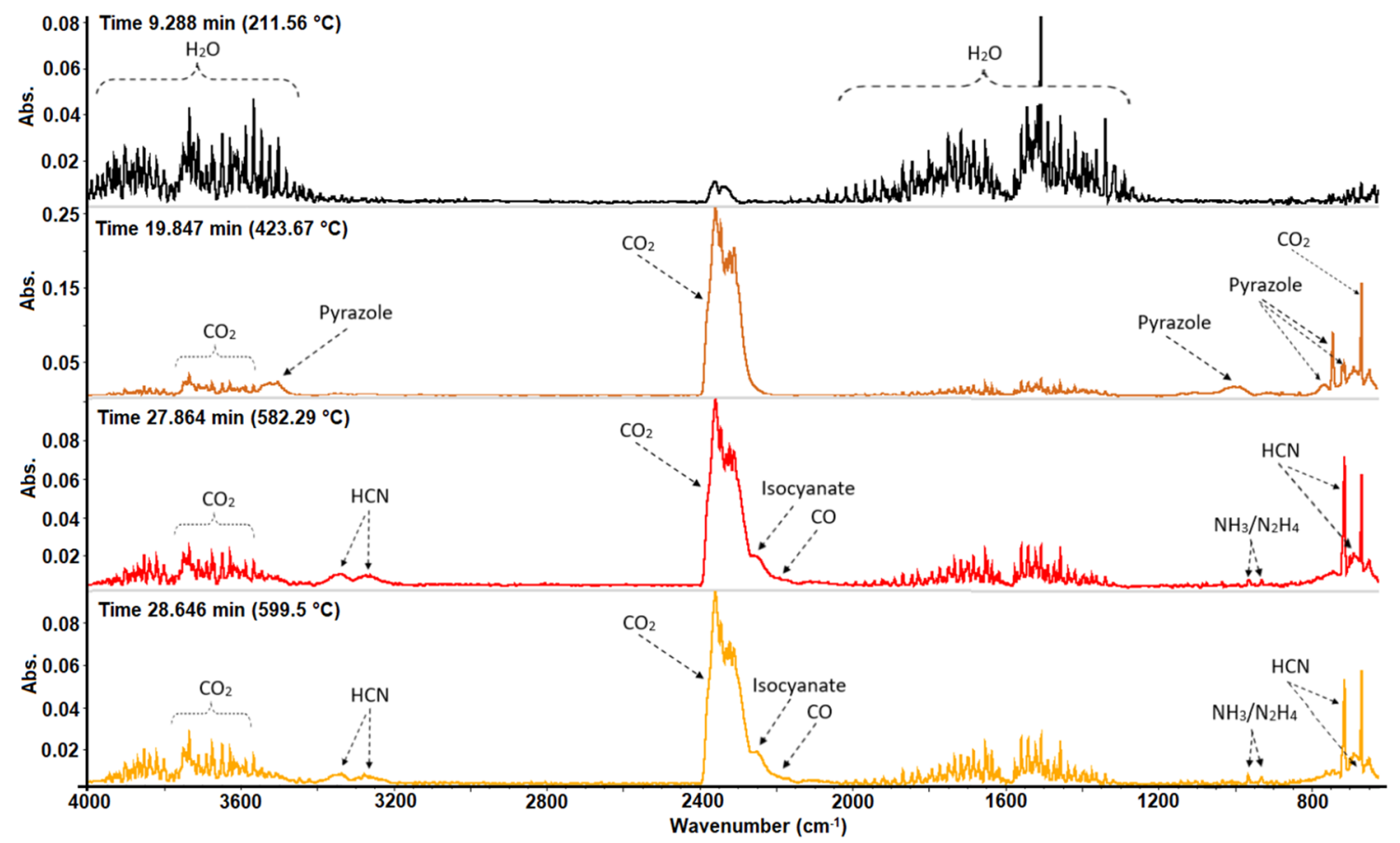

Fig. 12 The FTIR spectra of volatile products of $\mathrm{Eu}_{2}(\mathrm{Hpdca})_{3} \cdot 6 \mathrm{H}_{2} \mathrm{O}$ complex decomposition (nitrogen atmosphere)

that the carboxylate groups were bound with lanthanide centers in different modes, the $\mathrm{CO}_{2}$ molecules evolved continuously. It can be assumed that at the lowest temperature the monodentate $\mathrm{COO}$ groups were transformed into $\mathrm{CO}_{2}$ and next released from the structure. On the other hand, the carboxylate groups which participated in the formation of a five-membered ring as a result of coordination lanthanide atom by carboxylate oxygen atom and adjacent nitrogen atom from the pyrazole ring are more strongly bound due to high thermal stability of such 


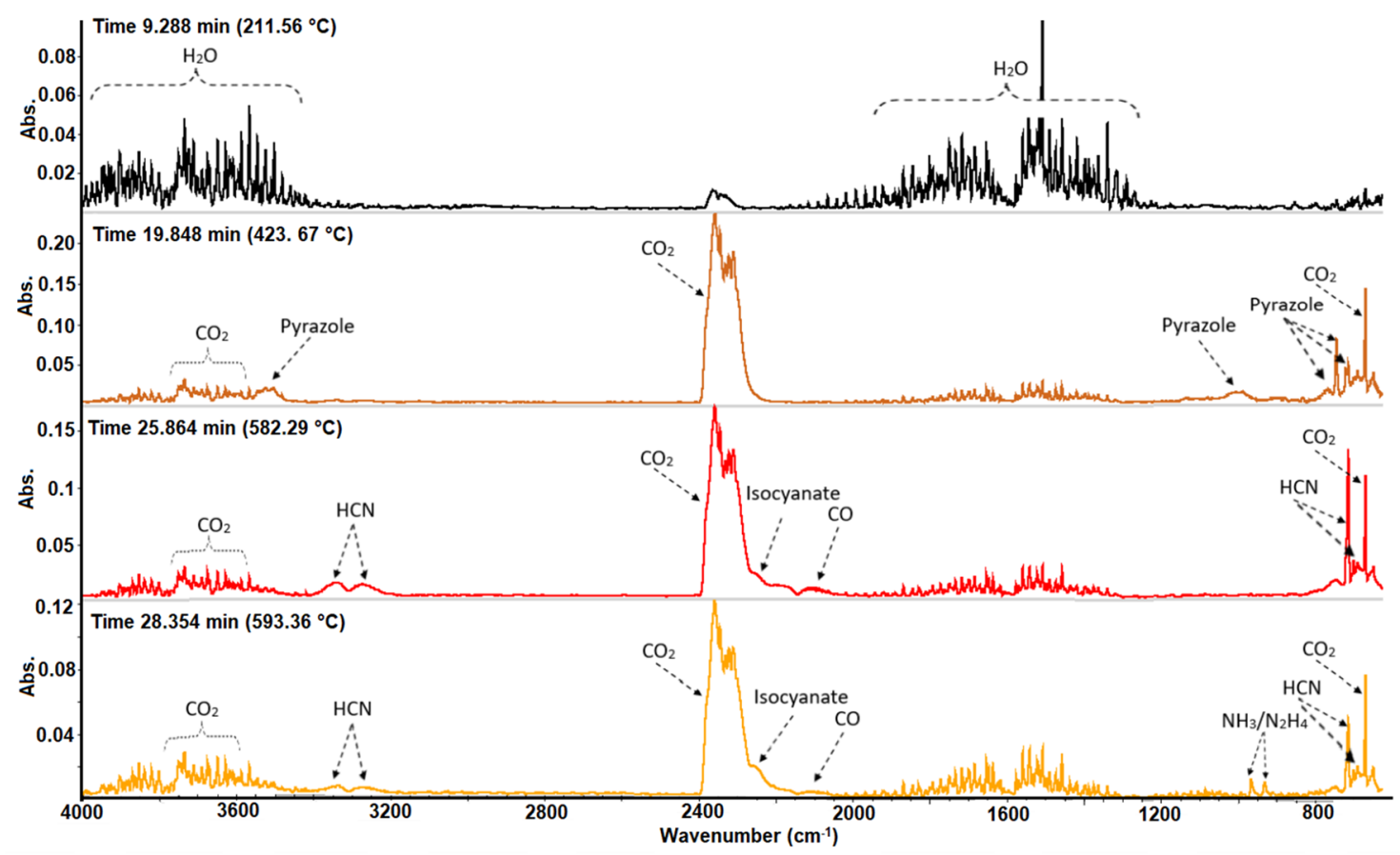

Fig. 13 The FTIR spectra of volatile products of $\mathrm{Tb}_{2}(\mathrm{Hpdca})_{3} \cdot 6 \mathrm{H}_{2} \mathrm{O}$ complex decomposition (nitrogen atmosphere)

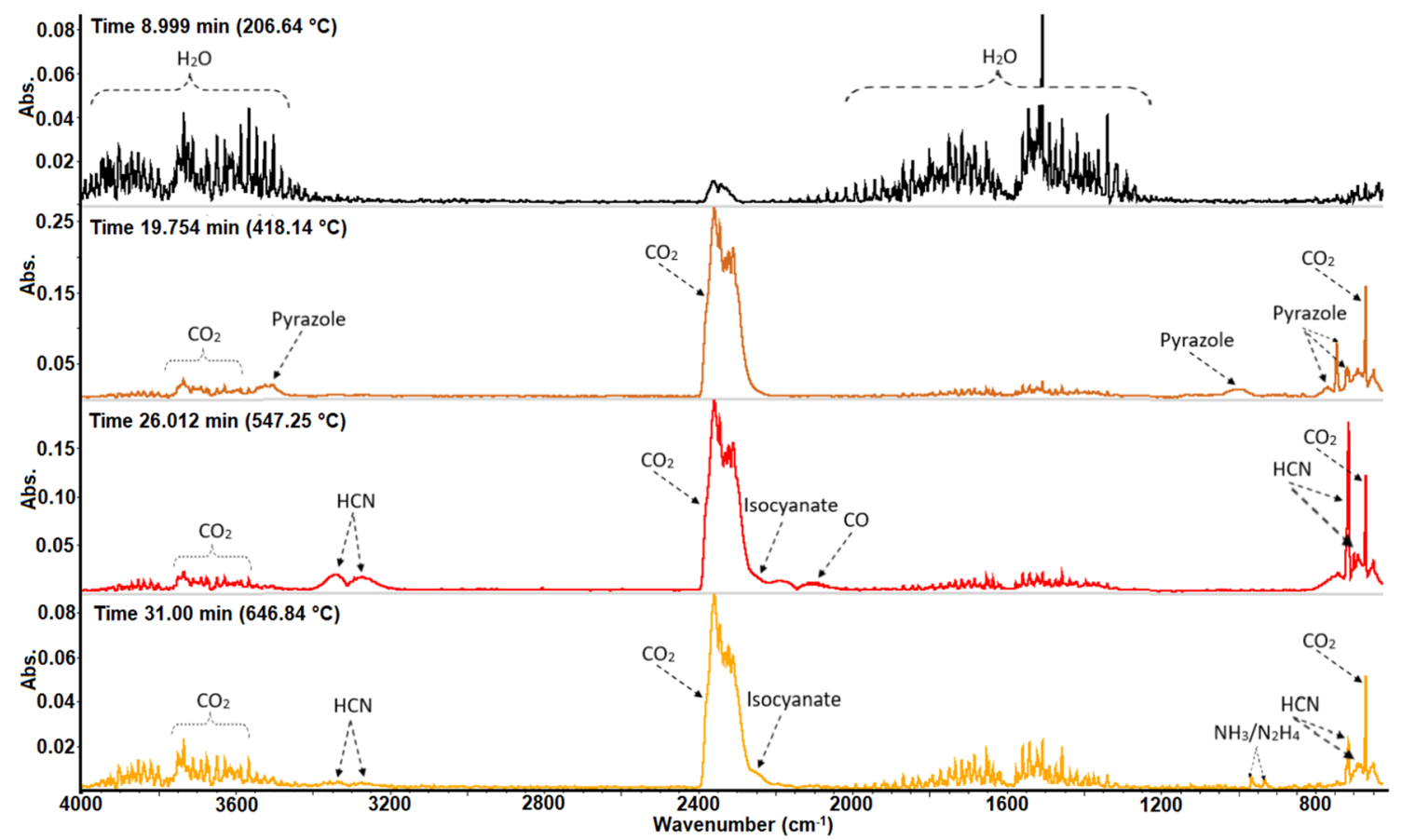

Fig. 14 The FTIR spectra of volatile products of $\mathrm{Er}_{2}(\mathrm{Hpdca})_{3} \cdot 6 \mathrm{H}_{2} \mathrm{O}$ complex decomposition (nitrogen atmosphere)

chelate moieties. That is why the decarboxylation process of such groups occurs at a higher temperature. The detailed analysis of the gaseous products of complexes decomposition (Table 2) along with the temperature of their evolution allowed finding the pyrazole molecules as a product of organic linker decomposition. Interestingly, only decomposition of $\mathrm{Eu}, \mathrm{Tb}$ and Er complexes leads to the pyrazole molecules evolution in the temperature range $386.78-446.42{ }^{\circ} \mathrm{C}$. Broad absorption bands in the ranges of 3600-3400, 1500-1350, 1150-1100, 1050-950 cm 


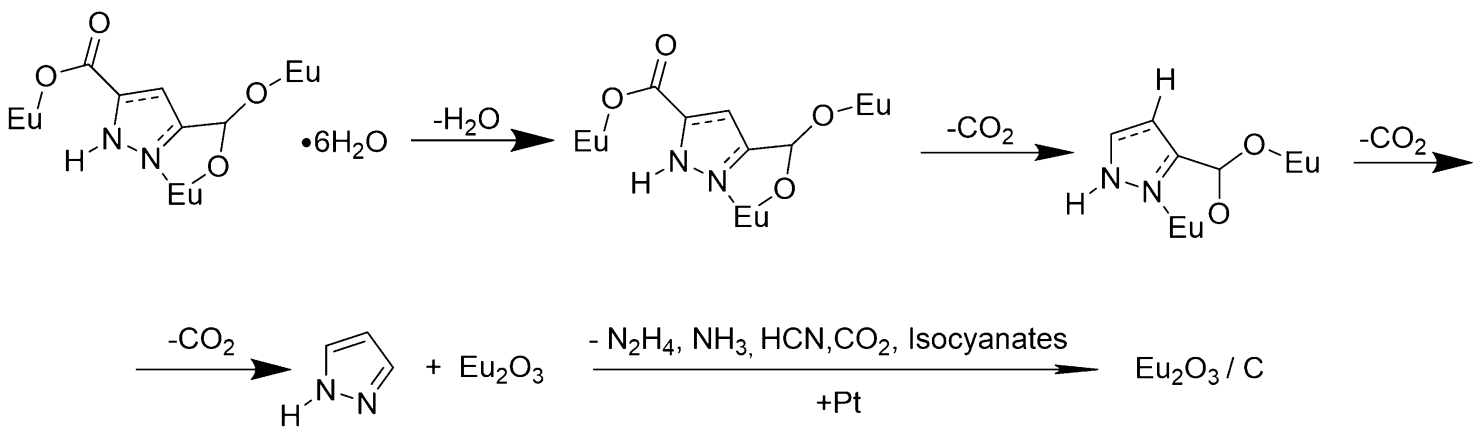

Fig. 15 Proposed pyrolysis mechanism for $\mathrm{Eu}_{2}(\mathrm{Hpdca})_{3} \cdot 6 \mathrm{H}_{2} \mathrm{O}$ complex

and sharp bands with a wavenumber at 750, 725 and 775 $\mathrm{cm}^{-1}$ testify to the vibrations of the pyrazole molecule. The lack of pyrazole molecules among volatile products of neodymium complex thermal decomposition can be explained in terms of its different crystal structure.

In the further stage of decomposition, such gases as hydrogen cyanide, hydrazine, ammonia, and isocyanates are released. The bands in the ranges 3400-3200, 1450-1380 and 750-650 $\mathrm{cm}^{-1}$ originated from the stretching vibrations of $\mathrm{C}-\mathrm{H}$ and $\mathrm{C}=\mathrm{N}$ groups of evolved hydrogen cyanide molecules. The ammonia and hydrazine molecules give very weak bands in the range $3350-3195 \mathrm{~cm}^{-1}$ and double band with maxima at 970 and $930 \mathrm{~cm}^{-1}$ assigned to the stretching and deformation vibrations of $\mathrm{N}-\mathrm{H}$ groups, respectively [79]. The FTIR spectra of volatile products of complexes decomposition show diagnostic bands from the ammonia and hydrazine molecules in the temperature range $566-667{ }^{\circ} \mathrm{C}$. Hydrogen cyanide molecules are observed in the temperature range $446-667{ }^{\circ} \mathrm{C}$. The formation of these gases can be explained by decomposition of volatile pyrazole molecules. It can be assumed that during pyrolysis of the investigated complexes, some solid intermediate lanthanide compounds along with carbon residues are formed. These products may act as catalysts of pyrazole molecules decomposition. Additionally, the catalytic process can be enhanced by material of the crucibles i.e. platinum which is regarded as a catalyst of many reactions in the gaseous phase [79]. In comparison to the free acid decomposition, also aliphatic isocyanates (RNCO) are formed as volatile products of metal complexes decomposition. They give absorption bands in the range $2300-2200 \mathrm{~cm}^{-1}$ due to the asymmetric stretching vibrations of $-\mathrm{NCO}$ group $[79,82]$. It is worth noting that this gaseous product is formed from neodymium complex decomposition above $446{ }^{\circ} \mathrm{C}$ while from the other complexes above $586{ }^{\circ} \mathrm{C}$. Such differences in the temperature of isocyanate species emanation confirm a structural diversity of neodymium and other lanthanide complexes.

\section{Conclusions}

In summary, we have obtained the coordination polymers of $\mathrm{Nd}(\mathrm{III}), \mathrm{Eu}(\mathrm{III}), \mathrm{Tb}$ (III) and $\mathrm{Er}(\mathrm{III})$ ions with $H$-pyrazole-3,5-dicarboxylate linker by hydrothermal, mechanochemichal and precipitation methods. It is interesting to note that that all prepared coordination polymers are crystalline, even in the mechanochemistry approach. Different synthesis strategies allowed to obtain the same final products. The complexes of $\mathrm{Eu}(\mathrm{III}), \mathrm{Tb}(\mathrm{III})$ and $\mathrm{Er}(\mathrm{III})$ are isomorphous while the $\mathrm{Nd}(\mathrm{III})$ complexes exhibit a different crystal structure. Moreover, application of the hydrothermal method improved the crystallinity of synthesized materials which finally resulted in the formation of single crystals of the $\mathrm{Eu}(\mathrm{III})$ complex.

The hydrothermal conditions lead to the complexes with the highest thermal stability (except the neodymium complex) and the strongest bonding of water molecules. Considering further stages of complexes decomposition, it can be concluded that the way of energy supply during the synthesis does not affect on the thermal stability of intermediate products of complexes heating and the pathways of their decomposition are similar. The gaseous products of free acid and investigated complexes pyrolysis in the nitrogen atmosphere were identified. The free linker degradates mainly with formation of volatile products such as: water, carbon dioxide and pyrazole. The pyrolysis of metal complexes is strongly affected by their crystal structures. Water, carbon dioxide and some aliphatic isocyanates were identified as gaseous products of neodymium complex decomposition. The pyrolysis process of europium, terbium and erbium complexes took place with an entirely different mechanism. Degradation of those complexes in the nitrogen results in the formation of not only water and carbon dioxide molecules but also pyrazole molecules. Interestingly, compared to free acid also the products of pyrazole degradation such as: ammonia, hydrazine and hydrogen cyanide were distinguished. Considering this fact, it can be postulated that solid products 
of the lanthanide decomposition have catalytic influence on pyrazole molecules degradation.

Supplementary Information The online version contains supplementary material available at https://doi.org/10.1007/s10904-021-02018-w.

Open Access This article is licensed under a Creative Commons Attribution 4.0 International License, which permits use, sharing, adaptation, distribution and reproduction in any medium or format, as long as you give appropriate credit to the original author(s) and the source, provide a link to the Creative Commons licence, and indicate if changes were made. The images or other third party material in this article are included in the article's Creative Commons licence, unless indicated otherwise in a credit line to the material. If material is not included in the article's Creative Commons licence and your intended use is not permitted by statutory regulation or exceeds the permitted use, you will need to obtain permission directly from the copyright holder. To view a copy of this licence, visit http://creativecommons.org/licenses/by/4.0/.

\section{References}

1. Ch. Janiak, J.K. Vieth, New J. Chem. 34, 2366 (2010)

2. M. Eddaoudi, H. Li, O.M. Yaghi, J. Am. Chem. Soc. 122, 1391 (2000)

3. S.L. James, Chem. Soc. Rev. 32, 276 (2003)

4. M.D. Allendorf, V. Stavila, Cryst. Eng. Comm. 17, 229 (2015)

5. S. Kitagawa, R. Kitaura, S. Noro, Angew. Chem. Int. Ed. 43, 2334 (2005)

6. J.R. Li, R.J. Kuppler, H.C. Zhou, Chem. Soc. Rev. 38, 1477 (2009)

7. A.R. Millward, O.M. Yaghi, J. Am. Chem. Soc. 127, 17998 (2005)

8. M.D. Allendorf, C.A. Bauer, R.K. Bhakta, R.J.T. Houk, Chem. Soc. Rev. 38, 1330 (2009)

9. J. Wen, Y. Fang, G. Zeng, Chemosphere 201, 627 (2018)

10. Kh.M. Elsabawy, A.M. Fallatah, J. Inorg, J. Inorg. Organomet. Polym. Mater. 28, 2865 (2018)

11. P. Horcajada, R. Gref, T. Baati, P.K. Allan, G. Maurin, P. Couvreur, G. Ferey, R.E. Morris, C. Serre, Chem. Rev. 112, 1232 (2012)

12. A. Corma, H. Garcı'a, F.X. Llabre's i Xamena, Chem. Rev. 110, $4606(2010)$

13. M. Eddaoudi, J. Kim, N.L. Rosi, D.T. Vodak, J. Wachter, M. O'Keeffe, O.M. Yaghi, Science 295, 469 (2002)

14. S.Y. You, L. Li, J.Y. Zou, K.H. Chen, S.W. Zhang, J. Inorg, J. Inorg. Organomet. Polym. Mater. 30, 410 (2020)

15. L.E. Kreno, K. Leong, O.K. Farha, M. Allendorf, R.P. Van Duyne, J.T. Hupp, Chem. Rev. 112, 1105 (2012)

16. K. Vellingiri, A. Deep, K.H. Kim, A.C.S. Appl, Mater. Interfaces 8, 29835 (2016)

17. B. Chocarro-Ruiz, J. Pérez-Carvajal, C. Avci, O. Calvo-Lozano, M.I. Alonso, D. Maspoch, L.M. Lechuga, J. Mater. Chem. A 6, $13171(2018)$

18. Y. Yang, X.X. Qi, H.R. Chen, X.Y. Wang, X.L. Yang, Y.Y. Tu, T. Zhou, T. Jiang, F. Wang, Z. Chen, Y.C. Ju, J. Inorg, J. Inorg. Organomet. Polym. Mater. 30, 4289 (2020)

19. Y. Hasegawa, Y. Kitagawa, J. Mater. Chem. C 7, 7494 (2019)

20. D. Wei, Y. Xin, Y. Rong, Y. Li, C. Zhang, Q. Chen, S. Qin, W, Wang, Y, Hao. J Inorg. Organomet. Polym. Mater. 30, 1121 (2020)

21. W.P. Lustig, J. Li, Coord. Chem. Rev. 373, 116 (2018)
22. B. Li, Y.Y. Jiang, Y.Y. Sun, Y.J. Wang, M.L. Han, Y.P. Wu, L.F. Ma, D.S. Li, Dalton Trans. 49, 14854 (2020)

23. B. Chen, G. Qian, Metal-Organic Frameworks for Photonics Applications (Springer, Berlin, 2014), pp. 27-80

24. D. Huang, X. Wu, J. Tian, X. Wang, Z. Zhou, D. Li, Chin. Chem. Lett. 19, 845 (2018)

25. W.P. Lustig, S. Mukherjee, N.D. Rudd, A.V. Desai, J. Li, S.K. Ghosh, Chem. Soc. Rev. 46, 3242 (2017)

26. W. Zhou, D.D. Huan, Y.P. Wu, J. Zhao, T. Wu, J. Zhang, D.S. Li, C. Sun, P. Feng, X. Bu, Angew. Chem. Int. Ed. 58, 4227 (2019)

27. M.L. Han, G.X. Wen, W.W. Dong, Z.H. Zhou, Y.P. Wu, J. Zhao, D.S. Li, L.F. Ma, X. Bu, J. Mater. Chem. C 5, 8469 (2017)

28. M. Dincă, F. Léonard, MRS Bull. 41, 854 (2016)

29. C. Pagis, M. Ferbinteanu, G. Rothenberg, S. Tanase, ACS Catal. 6, 6063 (2016)

30. Y. Zhao, Z. Song, X. Li, Q. Sun, N. Cheng, S. Lawes, X. Sun, Energy Storage Mater. 2, 35 (2016)

31. H. Li, Y. Li, H. Cheng, Q. Yang, J. Xiong, Y. Ma, L. Ding, C. Zeng, J. Inorg, J. Inorg. Organomet. Polym. Mater. 30, 2645 (2020)

32. Y. Chen, S. Ma, Rev. Inorg. Chem. 32, 81 (2012)

33. B. Lia, H.M. Wen, Y. Cui, G. Qian, B. Chen, Prog. Polym. Sci. 48, 40 (2015)

34. M.D. Allendorf, C.A. Bauer, R.K. Bhaktaa, R.J.T. Houka, Chem. Soc. Rev. 38, 1330 (2009)

35. M. Kumar, H.N. Sheikh, A. Fraconetti, J.K. Zaręba, S.C. Sahoo, A. Frontera, New J. Chem. 43, 2179 (2019)

36. L. Zhao-Hao, L.P. Xue, L.L. Shan, B.T. Zhao, J. Kan, W.P. Su, Cryst. Eng. Comm. 16, 10824 (2014)

37. R. Łyszczek, J. Anal. Appl. Pyrolysis. 86, 239 (2009)

38. R. Łyszczek, L. Mazur, Polyhedron 41, 7 (2012)

39. L. Pan, N. Ching, X. Huang, J. Li, Chem. Eur. J. 7, 4431 (2001)

40. C. Janiak, Dalton Trans. (2003). https://doi.org/10.1039/b305705b

41. G.X. Zhang, W. Zhang, Z. Han, Inorg. Chem. Commun. 12, 982 (2009)

42. J. Zhao, L. La-Sheng, H. Rong-Bin, L.S. Zheng, Dalton Trans. (2008). https://doi.org/10.1039/b806615a

43. R. Seetharaj, P.V. Vandana, P. Arya, S. Mathew, Arab. J. Chem. 12, 295 (2019)

44. L. Pan, T. Frydel, M.B. Sander, X. Huang, J. Li, Inorg. Chem. 40, $1271(2001)$

45. Y.R. Lee, J. Kim, W.S. Ah, Korean J. Chem. Eng. 30, 1667 (2013)

46. N. Stock, S. Biswas, Chem. Rev. 112, 933 (2012)

47. R. Łyszczek, L. Mazur, A. Ostasz, A. Bartyzel, H. Głuchowska, Sci. Technol. 35, 677 (2017)

48. R. Łyszczek, I. Rusinek, J. Sienkiewicz-Gromiuk, M. Iwan, O. Pavlyuk, Polyhedron 159, 93 (2019)

49. R. Łyszczek, H. Głuchowska, B. Cristóvão, B. Tarasiuk, Thermochim. Acta 645, 16 (2016)

50. R. Łyszczek, Z. Rzączyńska, A. Kula, A. Gładysz-Płaska, J. Anal. Appl. Pyrolysis 92, 347 (2011)

51. D.J. Tranchemontagne, J.R. Hunt, O.M. Yaghi, Tetrahedron 64, $8553(2008)$

52. W. Mori, S. Takamizawa, J. Solid State Chem. 152, 120 (2000)

53. D. Chen, J. Zhao, P. Zhang, S. Dai, Polyhedron 162, 59 (2019)

54. Z. Wang, Z. Li, M. Ng, P.J. Milner, Dalton Trans. (2020). https:// doi.org/10.1039/d0dt01240h

55. M. Klimakow, P. Klobes, A.F. Thunemann, K. Rademann, F. Emmerling, Chem. Mater. 22, 5216 (2010)

56. R. Łyszczek, A. Ostasz, A. Bartyzel, A. Lipke, J. Anal. Appl. Pyrolysis 92, 347 (2011)

57. A. Ostasz, R. Łyszczek, L. Mazur, J. Sienkiewicz-Gromiuk, I. Rusinek, Z. Rzączyńska, J. Anal. Appl. Pyrolysis 99, 203 (2013)

58. R. Łyszczek, J. Therm. Anal. Calorim. 108, 1101 (2012)

59. R. Łyszczek, L. Mazur, Cent. Eur. J. Chem. 10, 1165 (2012)

60. R. Łyszczek, L. Mazur, Inorg. Chem. Commun. 15, 121 (2012) 
61. R. Łyszczek, M. Iwan, J. Therm. Anal. Calorim. 103, 633 (2011)

62. R. Łyszczek, Thermochim. Acta 509, 120 (2010)

63. R. Łyszczek, J. Therm. Anal. Calorim. 93, 833 (2008)

64. M. Iwan, R. Łyszczek, A. Ostasz, Z. Rzączyńska, J. Therm. Anal. Calorim. 88, 157 (2007)

65. N. Ching, L. Pan, X.Y. Huang, J. Li, Acta Cryst. C 56, 1124 (2000)

66. S. Fa-Nia, Y. Ting-Hai, Inorg. Chim. Acta. 412, 79 (2014)

67. Y. Xing, Y. Liu, X. Xue, X. Wang, L. Wei, Inorg. Chem. Commun. 84, 153 (2017)

68. J. Qi, Q.L. Wang, A.P. Zhang, J.L. Tian, Y. Shi-Ping, P. Cheng, Y. Guang-Ming, L. Dai-Zheng, C. R. Chim. 17, 490 (2014)

69. K.M. Szécsényi, V.M. Leovac, R. Petkovi, K. Jaimovi, G. Pokol, J. Therm. Anal. Calorim. 90, 899 (2007)

70. B. Barta Holló, L.S. Vojinović Ješić, M.M. Radanović, M.V. Rodić, ŽK. Jaćimović, K.M. Szécsényi, J. Therm. Anal. Calorim. 142, 451 (2020)

71. L. Pan, X. Huang, J. Li, Y. Wu, N. Zheg, Angew. Chem. Int. Ed. 39, $527(2000)$

72. J. Xia, B. Zhao, H.-S. Wang, W. Shi, Y. Ma, S. Hai-Bing, P. Cheng, L. Dai-Zheng, Y. Shi-Ping, Inorg. Chem. 9, 3450 (2007)

73. J. Zhao, L.S. Long, R.B. Huang, L.S. Zheng, Dalton Trans. (2007). https://doi.org/10.1039/c001537g

74. CrysAlis PRO, Agilent Technologies Ltd, Yarnton, Oxfordshire, UK (2013)
75. G.M. Sheldrick, Acta Crystallogr. A 64, 112 (2008)

76. R.M. Silverstein, F.X. Webster, D.J. Kiemle, Spectrometric Identification of Organic Compounds (Wiley, New York, 1998), pp. $546-553$

77. S. Holly, P. Sohár, Absorption Spectra in the Infrared Region, Theoretical and Technical Introduction (Akadémiai Kiadó, Budapest, 1975), pp. 80-160

78. T.N. Wassermann, C.A. Rice, M.A. Suhma, J. Chem. Phys. 127, 234 (2007)

79. R. Łyszczek, A. Bartyzel, H. Głuchowska, L. Mazur, M. Sztanke, K. Sztanke, J. Anal. Appl. Pyrolysis 135, 141 (2018)

80. R. Łyszczek, M. Gil, H. Głuchowska, B. Podkościelna, A. Lipke, P. Mergo, Eur. Polym. J. 106, 318 (2018)

81. R. Łyszczek, B. Podkościelna, A. Lipke, A. Ostasz, A. Puszka, J. Therm. Anal. Calorim. 138, 4463 (2019)

82. W.J. Balfour, S.G. Fougere, D. Klapstein, W.M. Nau, Can. J. Chem. 71, 1627 (1993)

Publisher's Note Springer Nature remains neutral with regard to jurisdictional claims in published maps and institutional affiliations. 